\author{
Silvio Čović, dipl. iur." \\ Predsjednik Upravnog suda u Splitu
}

\title{
AKTUALNA UPRAVNOSUDSKA PRAKSA U POSTUPKU JAVNE NABAVE
}

\author{
UDK: 35.07 (497.5) \\ Pregledni rad \\ Primljeno: 15. 12. 2016.
}

\begin{abstract}
U uvjetima prisutnih složenih $i$ teških gospodarskih $i$ socijalnih prilika, a s obzirom na komparativne mogućnosti i ekonomske učinke, sustav javne nabave, koji je, u prvom redu, na zakonskoj razini, uređen Zakonom o javnoj nabavi iz 2011. godine (dalje: ZJN), od izuzetne je važnosti za čitav pravni, politički i gospodarski sustav Republike Hrvatske. Javna nabava, u svojoj biti, predstavlja ugovaranje nabave robe, radova ili usluga. Specifičnost tog sustava sastoji se, prije svega, u tome da regulira ulazak u ugovorni odnos javnog i privatnog sektora. Stoga, ovaj sustav načelno mora biti formalan, kako bi se zaštitila ravnopravnost natjecatelja u postupku javne nabave, ali i opći interes. Temeljni ciljevi autora bili su, cijeneći pravnu tradiciju i tuzemne posebnosti, nakon analize upravno-sudske prakse, u kontekstu međunarodne pravne stečevine, dati prikaz i analizu zakonske regulacije nekih u praksi spornih aspekata sustava javne nabave u Hrvatskoj, te dvojbi proizašlih iz aktualne upravno-sudske prakse. Sporni aspekti sustava javne nabave, analizom pravomoćnih odluka upravnih sudova u razdoblju primjene Zakona o upravnim sporovima iz 2010. godine (dalje: ZUS), tiču se prvenstveno pitanja: mjesne nadležnosti upravnih sudova-; (ne)poštovanja načela tržišnog natjecanja, jednakog tretmana, zabrane diskriminacije $i$ razmjernosti u odnosu na sve gospodarske subjekte; tko bi bili obveznici primjene ZJN-a; razloga isključenja i uvjeta sposobnosti gospodarskih subjekata; sadržaja, načina izrade i postupanja s dokumentacijom za nadmetanje te pristiglim ponudama; nadležnosti Državne komisije za rješavanje o žalbama; pravne zaštite kroz institut žalbe te naknade troškova žalbenog postupka. Stav je autora da pozitivno pravno uređenje sustava javne nabave u određenim segmentima opterećuje površnost $i$ nedorečenost propisa, što je otežalo rad primjenjivačima propisa, ali $i$ da postoji neki važni segmenti u regulativi i praksi koji zahtijevaju dodatnu analizu. Dotle, aktualnu upravno-sudsku praksu kao izvora prava, kada govorimo o predmetima javne nabave, obilježilo je nekoliko temeljnih značajki: fragmentarnost, s obzirom na to da je mali broj odluka uopće osporavan pred upravnim sudovima; nepotpunost, jer značajan broj odluka prvostupanjskih upravnih sudova nije podvrgnut ocjeni zakonitosti u žalbenom postupku; raznolikost u postupanju u određenim segmentima javne nabave te neaktualnost. K tome, u praksi je zabilježen značajan broj slučajeva u kojima se Državna komisija u ponovnom postupku, u izvršenju pravomoćnih presuda, suprotno članku 81. ZUS-a, nije pridržavala pravnih shvaćanja i primjedaba upravnog suda, što nitko sebi ne bi smio dopustiti. Međutim, očekivati je u narednom razdoblju da će značajniju ulogu u ujednačavanju upravnopravne prakse i primjene prava u postupcima javne nabave imati Visoki upravni sud Republike Hrvatske, što i jest njegova osnovna zadaća. To će ujedno doprinijeti učinkovitijoj zaštiti pravne sigurnosti svih dionika koji sudjeluju u ovim vrstama postupaka.
\end{abstract}

1 * Silvio Čović, dipl. iur., sudac i predsjednik Upravnog suda u Splitu. 
Ključne riječi: javna nabava; javni naručitelj; gospodarski subjekt; načelo tržišnog natjecanja; jednaki tretman; zabrana diskriminacije; načelo razmjernosti; razlozi isključenja; uvjeti sposobnosti; dokumentacija za nadmetanje, predmet nabave, tehničke specifikacije; ponuda; pravna zaštita; pravo na žalbu; troškovi postupka; Državna komisija; upravni spor

\section{UVOD}

\subsection{Općenito}

Svaka država je dužna, u skladu s temeljnim načelima svoga pravnog poretka, ${ }^{2}$ razviti i provesti te održavati djelotvornom usklađenu politiku koja promiče načela vladavine prava, pravne sigurnosti, pravilnog upravljanja javnim poslovima i javnom imovinom, čestitost, transparentnost i odgovornost. ${ }^{3} \mathrm{~S}$ tim u vezi, svaka država je u obvezi nastojati uvesti i promicati djelotvorne načine djelovanja u cilju sprečavanja sukoba interesa i koruptivnih ponašanja, ali i s vremena na vrijeme preispitati relevantne pravne instrumente $\mathrm{i}$ administrativne mjere, kako bi ocijenila jesu li ti instrumenti prikladni i učinkoviti u praksi. Ovo se posebno odnosi na Hrvatsku, koja je, prema ljestvici Indeksa percepcije korupcije za 2015. godinu što ju je predstavio Transparency International Hrvatska, zauzela 50. mjesto od 168 zemalja na svijetu, ${ }^{4}$ što, iako se radi „samo“ o percepciji, predstavlja poražavajući podatak u borbi protiv korupcije. ${ }^{5}$

Upravo načela vladavine prava i pravne sigurnosti objektivnog pravnog poretka zahtijevaju od normotvorca da pravne norme budu dostupne adresatima $\mathrm{i}$ za njih predvidljive odnosno takve da oni mogu stvarno i konkretno znati svoja prava i obveze, kako bi prema njima mogli uskladiti svoja ponašanja. Postupanje u skladu s tim fundamentalnim načelima svakog pravnog poretka obveza je i državnih i svih drugih tijela koja, odlučujući o pravima, pravnim interesima i obvezama pravnih subjekata, primjenjuju pravo na konkretan slučaj.

Imajući u vidu učestale normativne promjene, prisutne nedorečenosti pojedinih mjerodavnih pravnih normi te složenost ove problematike, provođenje postupaka javne nabave zahtijeva široko znanje i praktično iskustvo svih dionika koji u njemu sudjeluju. Naime, nedorečenost pravne norme i neusklađenost propisa koji uređuju

2 Vidjeti čl. 3. Ustava Republike Hrvatske (NN, br. 56/90, 135/97, 8/98 - pročišćeni tekst, 113/00, 124/00 - pročišćeni tekst, 28/01, 41/01 - pročišćeni tekst, 55/01 - ispravak, 76/10, 85/10 - pročišćeni tekst i 5/14, u daljnjem tekstu: Ustav).

3 Čl. 5. st. 1. Konvencije Ujedinjenih naroda protiv korupcije (NN - MU, broj: 2/05).

4 Dostupno na: www.transparency.hr.

5 Kregar, po pitanju korupcije, cijeneći posebnosti domaćeg pravnog i političkog sustava, razlikuje tri stadija u definiranju i doživljaju karaktera korupcije u Hrvatskoj: 1) stadij prepoznavanja, 2) stadij normativnog optimizma i institucionalnog inženjeringa te 3) stadij stabilizacije institucija - Kregar, J., Korupcija: neznanje nije opravdanje, Centar za demokraciju i pravo, Zagreb, 2010., str. 2, 3 i 12. 
pojedinu pravnu materiju mogu uvelike otežati rad primjenjivačima propisa, ali i dovesti do neujednačenog tumačenja i primjene prava, odnosno do nejedinstvene prakse.

Stoga, a budući da je neprijeporno jedan od izvora prava, sudska praksa ima vrlo važnu ulogu u odlučivanju sudova i javnopravnih tijela, što se osobito odnosi i na predmete javne nabave. S prethodnim u vezi, ovaj izvor prava treba biti konzistentan te ne smije omogućavati donošenje različitih odluka prilikom rješavanja istovjetne činjenične i pravne osnove. ${ }^{6} \mathrm{~K}$ tome, praćenje i proučavanje upravnosudske prakse na području javne nabave od iznimne je važnosti jednako tako i naručiteljima koji pripremaju i provode postupke javne nabave, ali i natjecateljima i ponuditeljima koji sudjeluju u tim postupcima.

\subsection{Definiranje problema}

U uvjetima prisutnih složenih i teških gospodarskih i socijalnih prilika, a s obzirom na komparativne mogućnosti i ekonomske učinke, sustav javne nabave, koji je, u prvom redu, na zakonskoj razini, uređen Zakonom o javnoj nabavi, ${ }^{7}$ od izuzetne je važnosti za čitav pravni, politički i gospodarski sustav Republike Hrvatske. Prema službeno dostupnim podacima, ukupna vrijednost javne nabave u Hrvatskoj u 2015. iznosila je 40.583.697.729,00 kuna, s time da je udio ukupne vrijednosti javne nabave u BDP-u za 2015. godinu iznosio 12,14\%. ${ }^{8}$

Javna nabava, u svojoj biti, predstavlja ugovaranje nabave robe, radova ili usluga. Specifičnost tog sustava sastoji se, prije svega, u reguliranju ulaska u ugovorni odnos javnog i privatnog sektora. ${ }^{9}$ Stoga, ovaj sustav načelno mora biti formalan, kako bi se zaštitila ravnopravnost natjecatelja u postupku javne nabave, ali i opći interes, koji se ponajprije očituje u učinkovitosti i transparentnosti postupka vezanog za angažman javnih financijskih sredstava, prevenciju mogućih zloupotreba od strane naručitelja, te općenito u zaštiti objektivne zakonitosti, koja uključuje i zaštitu pravne sigurnosti.

Krajnji ciljevi promatranog sustava moraju biti, s jedne strane, izbjegavanje manipulacija, nepravilnosti, pogodovanja i potencijalnih sukoba interesa, a, s druge strane, postizanje najbolje vrijednosti uloženih novčanih sredstava te pojednostavljenje i jačanje učinkovitosti javnih nabava. ${ }^{10}$ Tim više što je upravo u području javne nabave umnogome moguće počinjenje različitih kaznenih djela,

6 Aviani, D., Đerđa, D., „Uniformno tumačenje i primjena prava te jedinstvenost sudske prakse u upravnom sudovanju“, Zbornik radova pravnog fakulteta u Splitu, Split, 2012., str. 369.

7 Zakon o javnoj nabavi (NN, br. 90/11, 83/13, 143/13 i 13/14, u daljnjem tekstu: ZJN).

8 Prema sadržaju Statističkog izvješća o javnoj nabavi u Hrvatskoj za 2015. Ministarstva gospodarstva, Uprave za sustav javne nabave iz lipnja 2016. - dostupno na: www.javna-nabava.hr/.../ Statisticko-izvjesce-JN-2015. pdf.

9 Tako Raguž, G., Blažević Z., Otvoreni postupak javne nabave kroz praksu Državne komisije za kontrolu postupaka javne nabave, ,Temporis savjetovanje“ d. o. o., Zagreb, 2014., Predgovor, str. IX.

10 Slično Ibidem bilj. 8. (Raguž i dr., 2014.), str. 28. 
osobito korupcijskih, koja, negativno utječući na proračun ali i na perspektivu ekonomskog rasta i razvoja, podrivaju same temelje svake uređene zemlje u koje spada i Hrvatska.

\subsection{Ciljevi istraživanja $i$ hipoteze}

Temeljni ciljevi autora bili su, cijeneći pravnu tradiciju i posebnosti hrvatskog pravnog sustava, nakon analize upravnosudske prakse koja je potkrijepljena provedenim istraživanjem i podacima iz službenih statistika, u kontekstu međunarodne pravne stečevine, dati prikaz i analizu zakonske regulacije nekih u praksi spornih aspekata sustava javne nabave u Republici Hrvatskoj, te dvojbi proizašlih iz aktualne (novije) upravnosudske prakse, sabranih prema pojedinim segmentima postupka javne nabave, uz kritički osvrt.

Sporni aspekti sustava javne nabave u Hrvatskoj ticali bi se prvenstveno pitanja: mjesne nadležnosti upravnih sudova u predmetima javne nabave; (ne)poštovanja temeljnih načela javne nabave; tko bi bili javni naručitelji odnosno obveznici primjene ZJN-a; razloga isključenja i uvjeta sposobnosti gospodarskih subjekata; sadržaja, načina izrade i postupanja s dokumentacijom za nadmetanje te pristiglim ponudama; pravne zaštite kroz institut žalbe te naknade troškova žalbenog postupka.

Stav je autora da pozitivnopravno uređenje sustava javne nabave opterećuje u određenim segmentima površnost i nedorečenost propisa, što je otežalo rad primjenjivačima propisa u javnopravnim tijelima i upravnoj grani sudovanja, ali i da postoje neki važni segmenti u regulativi i praksi koji zahtijevaju dodatnu analizu i praćenje. Dotle, aktualnu upravnosudsku praksu kao izvora prava, obilježilo je nekoliko temeljnih značajki: fragmentarnost, s obzirom na to da je mali broj odluka uopće osporavan pred upravnim sudovima; nepotpunost, jer značajan broj odluka prvostupanjskih upravnih sudova nije podvrgnut ocjeni zakonitosti u žalbenom postupku; raznolikost u postupanju u samo pojedinim segmentima javne nabave te neaktualnost. K tome, u praksi je zabilježen određen broj slučajeva u kojima se Državna komisija za kontrolu postupaka javne nabave, ${ }^{11} \mathrm{u}$ ponovnom postupku, u izvršenju pravomoćnih presuda, suprotno članku 81. Zakona o upravnim sporovima, ${ }^{12}$ nije pridržavala pravnih shvaćanja i primjedaba upravnog suda.

\subsection{Znanstvena opravdanost rada}

U hrvatskoj pravnoj doktrini gotovo da ne postoji literatura koja bi se, u okviru prisutne šire rasprave, posebno i sveobuhvatno, u kontekstu međunarodne pravne stečevine, bavila analizom novije upravnosudske prakse u postupcima javne nabave.

11 U daljnjem tekstu: Državna komisija.

12 Zakon o upravnim sporovima (NN, br. 20/10, 143/12, 152/14 i 94/16 - Odluka i rješenje Ustavnog suda poslovni broj U-I-2753/12 i dr. od 27. IX. 2016., u daljnjem tekstu: ZUS). 
Isto tako, primjena normativnih rješenja u praksi ukazuje na određene poteškoće i neujednačenost u provođenju postupaka javne nabave.

Stoga, cjelovito istraživanje odabrane teme neophodan je i logičan znanstvenoistraživački odabir, koji će bez sumnje dati potpuniji prikaz problematike javnih nabava, te biti vrijedan znanstveni doprinos pravnoj doktrini i upravno-pravnoj praksi. Štoviše, opravdanost ovog istraživanja proizlazi i iz, moglo bi se reći, općeprihvaćene pretpostavke da su reorganizacija javne službe ${ }^{13}$ i postizanje njezine učinkovitosti, što nije moguće bez sankcioniranja i eliminiranja onih koji krše kaznene i upravne norme te ugled javne službe, neki od temeljnih zahtjeva koje Hrvatska mora ispuniti kao članica Unije, ali i radi zaštite temeljnih najviših vrednota ustavnog poretka: jednakosti, socijalne pravde, poštovanja prava čovjeka, nepovredivosti vlasništva, očuvanja prirode i čovjekova okoliša i vladavine prava.

Društveno promatrano, značaj istraživanja ogledat će se i u doprinosu razvoju i kreiranju opće politike prevencije i suzbijanja potencijalnih sukoba interesa i činjenja korupcijskih kaznenih djela.

\subsection{Metodika rada}

Istraživanje provedeno u ovom radu bit će teorijsko-empirijsko. Dualizam u istraživačkom pristupu determiniran je predmetom istraživanja koji je sadržajno dualistički.

U radu su primijenjene razne metode, polazeći od dogmatske i teleološke metode, preko gramatičke, logičke, sistemske, pa do empirijske i empirijsko-kazuističke. Naime, uz pomoć teleološke metode, autor je pokušao utvrditi svrhu određene pravne norme, odnosno smisao normotvorca koji se htio njome postići, pritom koristeći i druge metode, kao primjerice: gramatičku koja polazi od tumačenja značenja riječi; logičku koja ima svoja specifična pravila primjene i izvođenja zaključaka te sistemsku kojom se utvrđuje smisao odredbe iz cjeline u kojoj je smještena. Od općeznanstvenih metoda, koristit će se hipotetičko-deduktivna metoda, dok će se od osnovnih metoda koristiti sve, pri čemu će naglasak biti na analizi, indukciji i generalizaciji.

U teorijskom dijelu dat ce se prikaz i analiza hrvatskog pozitivnopravnog uređenja nekih u praksi spornih aspekata sustava javne nabave, cijeneći međunarodni kontekst.

Empirijsko istraživanje podijeljeno je u dva dijela. Prvi dio odnosi se na analizu podataka iz službenih statistika o radu upravnih sudova koji sudjeluju u kreiranju sustava javne nabave. U drugom dijelu analizirat će se pravomoćne odluke upravnih

13 Pojam javna služba nastao je krajem 19. stoljeća u praksi francuskog Državnog savjeta (Conseil d'Etat). Prema izvornoj koncepciji državnog savjeta, javna služba označava se kao aktivnost uprave po načelima javnoga prava. O službeničkom statusu, službeničkom odnosu i temeljnim standardima službeničkog odnosa u međunarodnoj pravnoj stečevini vidjeti Čović, S., Juras, D., Vučkov, D., „Neka pitanja u regulaciji radnopravnog statusa državnih službenika“, Zbornik Pravnog fakulteta Sveučilišta u Rijeci, Rijeka, 2015., str. 645-670. 
sudova donesene u predmetima javne nabave. Istraživanje će se provesti na cijelom području Republike Hrvatske prema namjernom uzorku za razdoblje od 01. siječnja 2012. godine do 30. lipnja 2016. godine. Analizom statističkih podataka pokušat će se istražiti broj pokrenutih, riješenih i (ostalo) neriješenih predmeta javne nabave, zastupljenost ovih vrsta predmeta u ukupnom prilivu svih upravnih sporova te struktura pravomoćnih odluka. S druge strane, analizom pravomoćnih odluka nastojat će se istražiti dvojbe proizišle iz upravnosudske prakse, aktualna pravna shvaćanja i, krajnje, temeljne značajke upravnosudske prakse u predmetima javne nabave. Nakon provedenog istraživanja, provest će se statistička obrada podataka.

\section{PRAVNA STEČEVINA EUROPSKE UNIJE O JAVNOJ NABAVI}

\subsection{Načelno}

Analizu regulacije sustava javne nabave u Republici Hrvatskoj valja promatrati i u okviru težnje da se domaći pravni sustav približi pravnim standardima Europske unije. ${ }^{14}$ Naime, Republika Hrvatska se, člankom 69. Sporazuma o stabilizaciji i pridruživanju, ${ }^{15} \mathrm{i}$ obvezala osigurati postupno usklađivanje zakonodavstva s acquis communutaire Unije.

Cjelokupna građa Unije, koja se odnosi na javnu nabavu, obuhvaća: prvo, tzv. primarni zakonodavni okvir, drugo, tzv. sekundarni pravni okvir, treće, praksu Europskog suda, te četvrto, odluke Europske komisije. ${ }^{16}$

Primarni zakonodavni okvir čine načela koja su sadržana u osnivačkim ugovorima Unije, ${ }^{17}{ }^{18} \mathrm{i}$ to načela nediskriminacije, jednakog tretmana, transparentnosti, razmjernosti i uzajamnog priznavanja. ${ }^{19}$

14 Republike Hrvatska je 1. srpnja 2013. postala punopravna članica EU.

15 Sporazum o stabilizaciji i pridruživanju sklopljen je između Republike Hrvatske i EU i država članica EU 29. listopada 2001., a stupio je na snagu 1. veljače 2005.

16 Tako Ljubanović, B., Britvić-Vetma, B., „Hrvatsko pravo javne nabave - usklađenost s pravom EU“, Zbornik radova Pravnog fakulteta u Splitu, 2011., str. 408.

17 Osnivačkim ugovorom omogućuje se svakoj europskoj državi kandidiranje za članstvo u Europskoj uniji (čl. 49. Ugovora o Europskoj uniji, Treaty on European Union (consolidated text), Official Journal C 83 of 30. III. 2010.) - dostupno na: www.eur-lex.europa.eu/en/treaties/index.htm.

18 Lisabonski ugovor, ratificiran 2009. godine, izmijenio je dotadašnje Osnivačke ugovore, unoseći amandmane na postojeći tekst Ugovora.

19 Ibidem bilj. 15. (Ljubnović i dr., 2011.), str. 409. 
U sekundarni pravni okvir spadaju direktive, uredbe Europske komisije, ${ }^{20}$ Vijeća i Parlamenta, te Jedinstveni rječnik javne nabave. ${ }^{21}$ Svrha navedenog rječnika sastoji se u ujednačenju postupka javne nabave, jer korištenje različitih kvalifikacija u tim postupcima, navodi se, ima za posljedicu nejednak tretman sudionika u postupku, ali i nemogućnost sudjelovanja u njemu. ${ }^{22}$

Krucijalnu ulogu u tumačenju, ali i u oblikovanju europskog prava javne nabave te provođenju postupaka javne nabave imao je i Europski sud. Naime, taj sud u svojim odlukama vrlo često rješava dvojbe i popunjava pravne praznine europskog zakonodavstva na ovom pravnom području. ${ }^{23} 24$

\subsection{Posebno o Direktivama}

Europska pravna stečevina po pitanju javne nabave uključuje nekoliko važnih direktiva. Tu, u prvom redu, spada Direktiva 2004/17/EC kojom se regulira koordinacija postupaka za dodjelu javnih ugovora u tzv. ,utility“ (gospodarskom) sektoru - vodoopskrba, energetika, prijevoz i poštanske usluge ${ }^{25} 26$ te Direktiva 2004/18/EC kojom se regulira koordinacija postupaka za dodjelu javnih ugovora u tzv. klasičnom sektoru. ${ }^{27} 28$

Pored ovih dviju, europska pravna stečevina o javnoj nabavi uključuje i Direktivu 89/665/EEZ za tzv. klasični sektor, Direktivu 92/13/EEZ za tzv. komunalni sektor. Obje su direktive izmijenjene i dopunjene Direktivom 2007/66/EZ, ali i

20 Uredba Komisije (EZ) br. 1150/2009 od 10. XI. 2009. kojom se izmjenjuje i dopunjuje Uredba Komisije (EZ) br. 1564/2005 vezano uz standardne obrasce za objavljivanje obavijesti u okviru postupaka javne nabave, prema Direktivama Vijeća 89/665/EEZ i 92/13/EEZ. Uz ovu, skrenuti je pozornost i na Uredbu Komisije (EZ) br. 1564/2005 od 7. IX. 2005. kojom se uspostavljaju standardni obrasci za objavljivanje obavijesti u javnoj nabavi.

21 Ibidem bilj. 15. (Ljubnović i dr., 2011.), str. 410.

22 Ibidem bilj. 15. (Ljubnović i dr., 2011.), str. 410 i 411.

23 Slično Ibidem bilj. 15. (Ljubnović i dr., 2011.), str. 411.

24 Ovdje valja skrenuti pozornost na neke presude Europskog suda broj: C-215/09, C-573/07, C-250/07, C-454/06, C-295/05, C-220/05, C-84/03, C-26/03 i C-107/98.

25 Directive 2004/17/EC of the European Parliament and of the Council of 31 March 2004 coordinating the procurement procedures of entities operating in the water, energy, transport and postal services sectors (OJL 134/04) 32004L0017, u daljnjem tekstu: Direktiva 2004/17/EC). Stavljena je izvan snage Direktivom 2014/25/EU Europskog parlamenta i Vijeća od 26. veljače 2014. o nabavi subjekata koji djeluju u sektoru vodnog gospodarstva, energetskom i prometnom sektoru te sektoru poštanskih usluga i stavljanju izvan snage Direktive 2004/18/EZ (Službeni list Europske unije, L 94/243 od 28. III. 2014.).

26 Prijevod ove direktive na hrvatskom jeziku dostupan na: www.dkom.hr/.../32004L0017hrv2.pdf.

27 Directive 2004/18/EC of the European Parliament and of the Council of 31 March 2004 on the coordination of procedures for the award of public works contracts, public supply contracts and public service contracts (OJ L 134/04, u daljnjem tekstu: Direktiva 2004/18/EC) 32004L0018. Stavljena je izvan snage Direktivom 2014/24/EU Europskog parlamenta i Vijeća od 26. veljače 2014. o javnoj nabavi $i$ stavljanju izvan snage Direktive 2004/18/EZ (Službeni list Europske unije, L 94/65 od 28. III. 2014.).

28 Prijevod ove direktive na hrvatskom jeziku dostupan na: www.sredisnjanabava.hr/.../ Direktiva2014/18EZpdf. 
Direktivom 2009/81/EZ Europskog parlamenta i Vijeća od 13. srpnja 2009. godine o usklađivanju postupka javne nabave za određene ugovore o radovima, ugovore o nabavi roba i ugovore o uslugama u području obrane i sigurnosti koje sklapaju javni naručitelj ili naručitelji.

Dodjela ugovora, pored navedenih direktiva, podlijegala je i općim načelima Ugovora o funkcioniranju Europske unije, posebno načelu slobodnog kretanja robe, slobode poslovnog nastana i slobode pružanja usluga, kao i načelima koja iz toga proizlaze, poput načela jednakog postupanja, nediskriminacije, međusobnog priznavanja, proporcionalnosti i transparentnosti, s obzirom na ekonomski i gospodarski aspekt javnih nabava. Naime, svaka ekonomska aktivnost pa tako i aktivnost javnopravnog tijela na dodjelu ugovora o javnoj nabavi podliježe pravilima o tržišnom natjecanju, a da bi se osiguralo slobodno tržišno nadmetanje i tržišno djelovanje javnopravnog tijela, Unija svojim pravilima ograničava djelovanje javne vlasti i prisiljava je da se u svojim ekonomskim aktivnostima ponaša tržišno.

U ovom dijelu, po mišljenju autora, valja pobliže skrenuti pozornost na prve dvije direktive: Direktivu 2004/17/EC i Direktivu 2004/18/EC.

\subsubsection{Direktiva 2004/17/EZ}

Ova direktiva, među ostalim, donesena je kako bi se zajamčilo otvaranje ugovora o javnoj nabavi tržišnom natjecanju, što ga dodjeljuju subjekti koji djeluju u sektoru vodnog gospodarstva, energetskom i prometnom sektoru te sektoru poštanskih usluga, te izradilo propise za usklađivanje ugovora iznad određene vrijednosti na razini Unije.

To usklađivanje temelji se na uvjetima koji se mogu zaključiti iz članaka 14., 28. i 49. Ugovora o osnivanju Europske zajednice i članka 97. Ugovora o osnivanju Europske zajednice za atomsku energiju, odnosno na načelima jednakog tretmana, uzajamnog povjerenja, razmjernosti i transparentnosti. Jedan od razlog za donošenja ove direktive sastojao se i u osiguranju otvaranja tržišta i pravedne ravnoteže u primjeni pravila o nabavi u predmetnim sektorima.

Važno je naglasiti da ova direktiva razlikuje ugovore o robi, radovima i uslugama. U dijelu temeljnih pojmova, direktiva, u članku 2.a), definira ugovore o robi, radovima $i$ uslugama kao ugovore za novčani iznos zaključene u pisanom obliku između jednog ili više ugovornih subjekata iz članka 2. stavka 2. i jednog ili više izvođača radova, dobavljača ili davatelja usluga. Iz ovoga možemo zaključiti da se nužno mora raditi o dvostranom pravnom odnosu financijske prirode. Takav ugovor mora biti sačinjen u pisanoj formi. Predmet ugovora je nabava: a) radova, b) roba ili c) usluga.

Pritom, ugovore o radovima definira kao ugovore čiji je predmet izvođenje radova ili projektiranje i izvođenje radova koji se odnose na jednu ili više djelatnosti u smislu Dodatka XII, ili posao, ili realizaciju bilo kakvim sredstvima posla koji odgovara zahtjevima što ih je naveo ugovorni subjekt. S tim u vezi, pojam posao, prema određenju direktive, definiran je kao rezultat gradnje ili građevinskih radova 
uzetih u cjelinu koji je sam po sebi dovoljan da ispuni gospodarsku ili tehničku funkciju (čl. 2.b).

Ugovore o robi određuje kao ugovore koji nisu ugovori iz točke (b) a čiji je predmet kupovina, uzimanje u najam, davanje u zakup, kupnja na otplatu, sa ili bez opcije kupnje, proizvoda. Isto tako, ugovor čiji je predmet isporuka proizvoda, a koji kao uzgrednu stvar obuhvaća i poslove postavljanja i instalacije, smatra se „ugovorom o robi“".

I krajnje, ugovore o uslugama kao ugovore koji nisu ugovori o radovima ili o robi, a čiji je predmet pružanje usluga iz Dodatka XVII (čl. 2.d).

U temeljna načela koja ističe direktiva, a koji se moraju poštovati od strane ugovornih subjekata u postupanju s gospodarskim čimbenicima u postupcima dodjele ugovora o javnoj nabavi, spadaju načelo jednakog i nediskriminirajućeg tretmana i transparentnosti. ${ }^{29}$

\subsubsection{Direktiva 2004/18/EZ}

I ova direktiva o koordinaciji postupaka za dodjelu ugovora o javnim uslugama, ugovora o javnim opskrbama i ugovora o pružanju javnih usluga, po uzoru na Direktivu 2004/17/EZ, donesena je upravo zbog toga kako bi se države članice, u dodjeli ugovora o javnoj nabavi, pridržavale temeljnih načela Ugovora o osnivanju Europske zajednice $\mathrm{u}$ postupcima iznad određene vrijednosti na razini Unije. ${ }^{30} \mathrm{Tu}$, u prvom redu, spadaju načelo slobode kretanja roba, načelo slobode osnivanja i načela slobode pružanja usluga te načela koja iz toga proizlaze kao što su načelo jednakog tretmana, načelo zabrane diskriminacije, načelo uzajamnog priznavanja, načelo razmjernosti i načelo transparentnosti. ${ }^{31}$

Ova direktiva posebno naglašava da bi se ugovore o javnoj nabavi trebalo dodjeljivati na temelju objektivnih kriterija koji osiguravaju načela transparentnosti, zabrane diskriminacije i jednakog tretmana i koja jamče da su ponude procijenjene u uvjetima učinkovitog tržišnog natjecanja. S time, napominje, da je, kao rezultat, prikladno dopustiti primjenu samo dvaju kriterija: „najniže cijene“ i „ekonomski najpovoljnije ponude“. .32

S prethodnim u vezi, kako bi se osiguralo poštovanje načela jednakog tretmana u dodjeli ugovora, direktiva određuje da je prikladno predvidjeti obvezu - koju je uspostavila sudska praksa - da se osigura nužna transparentnost, a u cilju omogućavanja da svi sudionici u natječaju budu razumno informirani o kriterijima i rješenjima koja će se primjenjivati u pronalaženju ekonomski najpovoljnije ponude. ${ }^{33}$ Stoga, odgovornost je naručitelja da pravovremeno navede kriterije za

29 Vidjeti čl. 10. Direktive2004/17/EZ.

$30 \mathrm{U}$ vezi područja primjene ove direktive vidjeti pragove navedene u čl. 7. (Poglavlje II - Područje primjene).

31 Vidjeti pobliže ,preambulu“ Direktive 2004/18EZ.

32 Vidjeti točku 46. uvodnog dijela Direktive 2004/18/EZ.

33 Ibidem. 
dodjelu ugovora i relativni značaj koji se pripisuje svakom od tih kriterija, kako bi sudionici u natječaju bili svjesni pri pripremanju svojih ponuda. ${ }^{34}$

S druge strane, kako bi se jamčio jednak tretman, direktiva ističe da bi kriteriji za dodjelu ugovora trebali omogućiti objektivno uspoređivanje i ocjenjivanje ponuda. $\mathrm{Pa}$, ako su ovi uvjeti ispunjeni, ekonomski i kvalitativni kriteriji za dodjelu ugovora, kao što je udovoljavanje ekološkim zahtjevima, mogu omogućiti da naručitelji zadovolje potrebe dotične javnosti kako je iskazano u specifikacijama ugovora. ${ }^{35}$

Što se tiče osnovnih pojmova, Direktiva 2004/18/EZ, po pitanju sustava javnih nabava, u članku 1. stavku 2., definira pojmove: a) ugovor o javnim nabavama, b) ugovor o javnim radovima, c) ugovor o javnim opskrbama i d) ugovore o pružanju javnih usluga.

Tako, ugovor o javnim nabavama, slično kao i Direktiva 2004/17/EZ, u članku 1. stavku 2. (a), definira kao ugovor s financijskim interesom sklopljenim u pisanom obliku između jednog ili više gospodarskih subjekata i jednog ili više naručitelja i koji imaju za predmet izvođenje radova, opskrbu proizvodima ili pružanje usluga u smislu ove Direktive. Dakle, zaključiti je, nužno se radi o dvostranom pravnom odnosu financijske prirode, koji mora biti sklopljen u točno određenoj formi (pisanom obliku). Predmet takvog ugovora moraju biti: a) izvođenje radova, ili b) opskrba proizvodima ili c) pružanje usluga.

Ugovori o javnim radovima, prema definiciji Direktive 2004/18/EZ iz članka 1. stavka 2. (b), ugovori su o javnim radovima koji za predmet imaju ili izvođenje, ili oboje, i dizajn i izvođenje radova vezanih uz jednu od djelatnosti u smislu Priloga I. ili djela ili realizacije, bilo kojim sredstvima, djela koje odgovara zahtjevima koje je naveo naručitelj. S tim u vezi, pod pojmom ,djela“ ova direktiva razumijeva rezultat radova u niskogradnji ili graditeljstvu uzeto kao cjelina dovoljna sama po sebi da ispuni ekonomsku ili tehničku funkciju.

Ugovori o javnim opskrbama, prema članku 1. stavku 2. (c), smatraju se ugovorima o javnim nabavama koji nisu oni navedeni pod (b), a koji za predmet imaju kupovinu, iznajmljivanje i leasing s odlukom o kupoprodaji proizvoda. Pritom, prema regulaciji direktive, ugovori o javnim nabavama koji za predmet imaju opskrbu proizvodima i koji također obuhvaćaju, kao uzgredan sadržaj, poslove ugrađivanja i radove na montaži smatraju se „ugovorima o javnim opskrbama“.

I na kraju, ugovor o pružanju javnih usluga određuje se kao ugovor o javnim nabavama koji nije ugovor o javnim radovima ni ugovor o javnim opskrbama i koji za predmet ima pružanje usluga navedenih u prilogu II. (čl. 1. st. 2. (d)).

Iznoseći o temeljnim načelima dodjele ugovora o javnoj nabavi, ova direktiva, u članku 2., slično kao i Direktiva 2004/17/EZ, određuje da se naručitelji prema gospodarskim subjektima moraju ponašati jednako i nediskriminirajuće, ali i na transparentan način.

\footnotetext{
34 Ibidem.

35 Ibidem.
} 


\section{HRVATSKO POZITIVNOPRAVNO UREĐENJE NEKIH U PRAKSI SPORNIH ASPEKATA SUSTAVA JAVNE NABAVE}

\subsection{Normativni okvir}

Sustav javne nabave u hrvatskom pravnom sustavu uređen je na zakonskoj razini, u prvom redu, Zakonom o javnoj nabavi iz 2011. ${ }^{36}$ koji je stupio na snagu 01. siječnja 2012. godine. Ovaj zakon, u odnosu na regulaciju Zakona o javnoj nabavi iz 2007. ${ }^{37}$ unosi značajne novosti u postupcima javne nabave, što se poglavito odnosi na pitanje pravne zaštite i uređenja žalbenog postupka koji se vodi pred Državnom komisijom. ${ }^{38}$ Kako se radi o upravnom postupku, u predmetima javne nabave pred Državnom komisijom, supsidijarno, primjenjuje se i Zakon o općem upravnom postupku. ${ }^{39}{ }^{40} \mathrm{Uz}$ usklađivanje s relevantnim propisima Europske unije, temeljni cilj ZJN-a sastojao se u pojednostavljenju i jačanju učinkovitosti postupaka javne nabave kroz ukidanje određenih administrativnih prepreka. ${ }^{41}$

Podzakonski, sustav javne nabave reguliran je, u prvom redu, Uredbom o načinu izrade i postupanju s dokumentacijom za nadmetanje i ponudama, ${ }^{42}$ Uredbom o objavama javne nabave, ${ }^{43}$ Uredbom o nadzoru nad provedbom Zakona o javnoj nabavi, ${ }^{44}$ Uredbom o javnoj nabavi za potrebe obrane i sigurnosti, ${ }^{45}$ Pravilnikom o popisu obveznika primjene Zakona o javnoj nabavi, ${ }^{46}$ Pravilnikom o primjeni jedinstvenog rječnika javne nabave ${ }^{47}$ te Pravilnikom o izobrazbi u području javne nabave..$^{48}$

36 Sustav javne nabave na zakonskoj razini uređen je i odredbama Zakona o koncesijama (NN, br. 143/12), Zakona o javno-privatnom partnerstvu (NN, br. 78/12 i 152/14) i Zakona o Državnoj komisiji za kontrolu postupaka javne nabave (NN, br. 18/13, 127/13 i 74/14, u daljnjem tekstu: Zakon o Državnoj komisiji).

37 Zakon o javnoj nabavi (NN, br. 110/07 i 125/08, u daljnjem tekstu: ZJN/07).

$38 \mathrm{O}$ sustavu javne nabave u institucionalnom smislu vidjeti Šuler, I., Lerman B., Zovko K., Palčić, I., Javna nabava - službeni stavovi $i$ sudska praksa, Tip4PIN d. o. o., Zagreb, 2015., uvodni dio, str. XVII-XX.

39 Zakon o općem upravnom postupku (NN, br. 47/09, u daljnjem tekstu: ZUP).

40 Na žalbeni postupak u predmetima javne nabave, primjenom općeg načela prava lex specialis derogat legi generali, primarno se primjenjuju odredbe ZJN-a kao specijalnog zakonskog propisa u pogledu pravne zaštite u postupcima javne nabave, a, podredno, ZUP kao opći zakonski propis koji uređuje upravni postupak općenito.

${ }_{41}$ Iz Obrazloženja Prijedloga Zakona o javnoj nabavi, s konačnim Prijedlogom Zakona o javnoj nabavi iz srpnja 2011. - dostupno na: www.sabor.hr/Default.aspx?art=40365.

42 Uredba o načinu izrade i postupanju s dokumentacijom za nadmetanje i ponudama (NN, br. 10/12).

43 Uredba o objavama javne nabave (NN, br. 10/12).

44 Uredba o nadzoru nad provedbom Zakona o javnoj nabavi (NN, br. 10/12).

45 Uredba o javnoj nabavi za potrebe obrane i sigurnosti (NN, br. 89/12 i 145/14).

46 Pravilnik o popisu obveznika primjene Zakona o javnoj nabavi (NN, br. 19/12).

47 Pravilnik o primjeni jedinstvenog rječnika javne nabave (CPV - NN, br. 6/12).

48 Pravilnik o izobrazbi u području javne nabave (NN, br. 6/12 i 125/14). 
Prema važećoj regulaciji, hrvatsko se pravo opredijelilo za tzv. „,mješoviti sustav javne nabave“. ${ }^{49}$ Naime, postupak javne nabave i dodjeljivanje javnog ugovora koji iz njega proizlazi vodi se kao upravni postupak, dok je sve ostalo, a tiče se izvršavanja takvih ugovora i rješavanje sporova koji iz njih proizlaze, podvrgnuto pravilima građanskoga prava ${ }^{50}$ Mišljenja je autor da ovakav pravni pristup u regulaciji valja „,novelirati“" na način da se i stadij nakon donošenja odluke o odabiru u postupcima javne nabave, dakle izvršavanje ugovora o javnoj nabavi i rješavanje sporova koji iz takvih ugovora proizlaze, podvrgne normama upravnog prava. ${ }^{51}$ Navedeno bi, po uzoru na pravni režim koncesija na pomorskom dobru u hrvatskom pravnom sustavu, ${ }^{52}$ bilo u suglasju i s regulacijom ZUP-a, ali i odredbama ZUS-a, prema kojem, u skladu s člankom 3. stavkom 1. točkom 4., predmet upravnog spora jest i ocjena zakonitosti sklapanja, raskidanja i izvršavanja upravnog ugovora. ${ }^{53} 54$

\subsection{Temeljna načela javne nabave}

ZJN, u članku 3. stavku 1., prilikom provođenja postupaka iz ovoga Zakona naručitelji su obvezni u odnosu na sve gospodarske subjekte poštovati načelo slobode kretanja robe, načelo slobode poslovnog nastana i načelo slobode pružanja usluga te načela koja iz toga proizlaze, kao što su načelo tržišnog natjecanja, načelo jednakog tretmana, načelo zabrane diskriminacije, načelo uzajamnog priznavanja, načelo razmjernosti i načelo transparentnosti.

$\mathrm{Na}$ temelju analize europske pravne stečevine o javnim nabavama, a cijeneći sadržaj navedene odredbe članka 3. ZJN-a, možemo slobodno zaključiti da je na izložen način hrvatski pravni sustav javne nabave prihvatio temeljna (opća) načela sadržana u osnivačkim ugovorima Europske unije, ali i u regulativi Direktive 2004/17/EZ i Direktive 2004/18/EZ. ${ }^{55}$

Pritom, ZJN, u općim odredbama, obvezuje naručitelje primjenjivati odredbe tog Zakona na način koji omogućava učinkovitu javnu nabavu te ekonomično trošenje sredstava za javnu nabavu (čl. 3. st. 2. ZJN-a).

49 Ibidem bilj. 15. (Ljubanović i dr., 2011.), str. 412.

50 Ibidem.

51 Slično Ibidem.

52 Čl. 27. Zakona o pomorskom dobru i morskim lukama (NN, br. 158/13, 100/04, 141/06, 38/09 i $123 / 11)$.

53 Ugovor o koncesiji predstavlja ugovor sui generis sklopljen između javnopravnog tijela i treće osobe koji po svojoj prirodi predstavlja tipičan upravni ugovor koji je kao takav podložan normama upravnog i građanskog prava, a sporove koji iz njega proizlaze rješavaju upravni sudovi na temelju članka 12. stavka 2. točke 4. ZUS-a.

54 Slično Ibidem bilj. 15. (Ljubanović i dr., 2011.), str. 412.

55 Vidjeti pobliže Glavu 2. ovog rada. 


\subsection{Javni naručitelji}

\section{ZJN, u članku 5., navodi tko bi bili javni naručitelji.}

Prema navedenoj zakonskoj odredbi, tu bi spadali: 1. Republika Hrvatska, odnosno državna tijela Republike Hrvatske, 2. jedinice lokalne i područne (regionalne) samouprave, 3. pravne osobe koje su osnovane za određene svrhe radi zadovoljavanja potreba u općem interesu, koje nemaju industrijski ili trgovački značaj i ispunjavaju jedan od sljedećih uvjeta: a) da se financiraju iz državnog proračuna ili iz proračuna jedinice lokalne odnosno iz proračuna jedinice područne (regionalne) samouprave ili sredstava drugih takvih pravnih osoba u iznosu većem od $50 \%$, ili b) da nadzor nad poslovanjem tih pravnih osoba obavljaju državna tijela, jedinice lokalne i područne (regionalne) samouprave ili druge takve pravne osobe, ili c) da više od polovice članova nadzornog odbora, uprave ili odgovarajućeg tijela za upravljanje te vođenje poslova imenuju državna tijela, jedinice lokalne i područne (regionalne) samouprave ili druge takve pravne osobe, te 4. zajednica tijela iz točaka 1. i 2. ovoga stavka ili pravnih osoba iz točke 3. ovoga stavka. K tome, Državna i druga tijela kao i pravne osobe koje ispunjavaju uvjete iz stavka 1. ovoga članka obvezni su primjenjivati ovaj Zakon i u slučaju kada nisu navedeni u pravilniku iz stavka 2. ovoga članka (čl. 5. st. 3. ZJN).

Na podzakonskoj razini, u ovom dijelu, skrenuti je pozornost na Pravilnik o popisu obveznika primjene Zakona o javnoj nabavi, koji je donesen na temelju zakonskog ovlaštenja iz članka 5. stavka 2 . ZJN-a, kojim je propisan popis javnih naručitelja iz članka 5. ZJN-a, ali i popis sektorskih naručitelja. ${ }^{56}$

\subsection{Dokumentacija za nadmetanje}

Člankom 79. ZJN-a regulirani su tehnički, tehnološki, funkcionalni i drugi kriteriji za određivanje predmeta nabave (st. 1.). Tim člankom, stavkom 2., naručitelju je dana mogućnost podjele predmeta nabave na grupe, pri čemu kriteriji nisu navedeni taksativno, već primjerično. Tako naručitelji mogu predmet nabave odijeliti na grupe na temelju objektivnih kriterija, primjerice prema vrsti, svojstvima, namjeni, mjestu ili vremenu ispunjenja.

Pritom, člankom 80. ZJN-a, određena su pravila opisa predmeta nabave. Prvo, predmet nabave mora se opisati na jasan, nedvojben, potpun i neutralan način koji osigurava usporedivost ponuda u pogledu uvjeta i zahtjeva koje je javni naručitelj postavio (st. 1.). Drugo, opis predmeta nabave ne smije pogodovati određenom gospodarskom subjektu (st. 2.). Treće, opis predmeta nabave mora sadržavati tehničke specifikacije koje se, ako je potrebno, nadopunjavaju nacrtima, projektnom dokumentacijom, crtežima, modelima, uzorcima i slično (st. 3.). Četvrto, u opisu predmeta nabave navode se sve okolnosti koje su značajne za izvršenje ugovora, a time i za izradu ponude kao što su mjesto izvršenja, rokovi izvršenja ili posebni

56 Vidjeti čl. 6. ZJN-a. 
zahtjevi u pogledu načina izvršavanja predmeta nabave, s time da isto vrijedi i za posebno otežavajuće ili olakšavajuće okolnosti. I, krajnje, peto, kod funkcionalnog opisa predmeta nabave mora biti prepoznatljiva svrha predmeta nabave i zahtjevi koji se postavljaju za predmet nabave u tehničkom, gospodarskom, oblikovnom i funkcionalnom pogledu (st. 5.).

Kao dio opisa i načina opisa predmeta nabave naručitelj tehničke specifikacije određuje u pozivu na nadmetanje i u dokumentaciji za nadmetanje (čl. 81. st. 1. ZJN-a). Pritom, važno je navesti da u slučaju kada opisuje predmet nabave kroz tehničke specifikacije, ZJN obvezuje naručitelje da oni moraju omogućiti jednak pristup ponuditeljima i ne smiju imati učinak stvaranja neopravdanih prepreka nadmetanju, ali moraju omogućiti i podnošenje ponuda koje odražavaju različitost tehničkih rješenja (čl. 81. st. 2.). ${ }^{57}$

Također, valja skrenuti pozornost da ZJN, u članku 81. kojima se reguliraju tehničke specifikacije, sadrži pravilo u vezi s opisom predmeta nabave kojim se određuje da naručitelj u tehničkoj specifikaciji, osim ako je to opravdano predmetom nabave, ne smije, u pravilu, upućivati na posebnu marku ili izvor, ili poseban proces, ili zaštitni znak, patente, tipove ili posebno podrijetlo ili proizvodnju, ako bi to imalo učinak pogodovanja ili isključenja određenih gospodarskih subjekata ili određenih proizvoda. Iznimno, takva uputa dopuštena je ako se predmet nabave ne može dovoljno precizno i razumljivo opisati na temelju stavaka 3. i 4. ovoga članka. Takve upute moraju se označiti s dodatkom ,ili jednakovrijedan“ (st. 10.). Dakle, iz ovog proizlazi da ZJN omogućuje naručiteljima da predmet nabave određuju u skladu sa svojim potrebama i da shodno tome određuju i predmet nabave kroz tehničke specifikacije, uz ograničenja iz Dodatka IV . te u vidu „kriterija jednakovrijednosti““

Regulirajući alternativno, ZJN, u članku 82. stavku 1., vezano za kriterije za odabir ponuda, predviđa: 1 . ako se odabire ekonomski najpovoljnija ponuda sa stajališta javnog naručitelja, različite kriterije povezane s predmetom nabave, primjerice: kvaliteta, cijena, tehničke prednosti, estetske i funkcionalne osobine, ekološke osobine, operativni troškovi, ekonomičnost, usluga nakon prodaje i tehnička pomoć, datum isporuke i rok isporuke ili rok izvršenja, ili 2. najnižu cijenu (čl. 82. st. 1.).

U skladu s međunarodnom pravnom stečevinom i posebno regulacijom Direktive 2004/18/EZ, domaći zakonodavac, u članku 82. stavku 2. ZJN-a, također je propisao da ako se odabire ekonomski najpovoljnija ponuda, javni naručitelj mora u pozivu na nadmetanje ili u dokumentaciji za nadmetanje, odnosno u slučaju natjecateljskog dijaloga u opisnoj dokumentaciji, navesti relativni značaj koji pridaje svakom pojedinom kriteriju. Ti se značaji mogu izraziti određivanjem raspona s odgovarajućom maksimalnom razlikom. Ako prema mišljenju javnog naručitelja,

57 Detaljnije o pravilima o načinu formuliranja tehničkih specifikacija vidjeti čl. 81. st. 3. do 10 . ZJN-a. 
iz dokazivih razloga, nije moguće navesti relativni značaj kriterija, on mora navesti sve kriterije po redoslijedu od najvažnijeg do najmanje važnog. ${ }^{58}$

\subsection{Ponuda}

Pravila o izradi, jeziku, pismu i valuti ponude, zatim o izmjeni, nadopuni ili odustanku od ponude, kao i o produljenju valjanosti ponude, sadržana su u članku 87. ZJN-a. ${ }^{59}$ Ono što valja istaknuti jest da se ponuditelj pri izradi ponude mora pridržavati zahtjeva i uvjeta iz dokumentacije za nadmetanje (čl. 87. st. 1. ZJN-a). Pritom, sve dokumente koje naručitelj može zahtijevati prema članku 67. do 74. gospodarski subjekti mogu dostaviti u neovjerenoj preslici, pod čim se smatra i neovjereni ispis elektroničke isprave (čl. 75. st. 1. ZJN-a).

Definicija alternativne ponude i kriteriji za odabir u slučaju kada naručitelj dopusti obnovu alternativnih ponuda, regulirani su u članku 88. ZJN-a, dok su javno otvaranje ponude te način pregleda i ocjene ponuda regulirani u odredbama članka 89. i 90. ZJN-a.

U dijelu regulacije postupanja s pristiglim ponudama, valja također skrenuti pozornost da ZJN, u članku 91. stavku 1. i 2., daje ovlast naručitelju da odbije ponudu ako je u istoj iskazana neuobičajeno niska cijena ponude ili neuobičajeno niska pojedina jedinična cijena što dovodi u sumnju mogućnost isporuke robe, izvođenja radova ili pružanja usluga koje su predmet nabave. Zaključiti je da primjena navedene ovlasti ovisi isključivo o slobodnoj ocjeni naručitelja, što znači da se njome može, ali i ne mora koristiti. Međutim, ako se naručitelj odluči koristiti ovom zakonskom ovlašću, dužan je prethodno, prije odbijanja ponude, zatražiti pisano objašnjenje s podacima o sastavnim elementima ponude koje smatra bitnima za izvršenje ugovora, u skladu s odredbom članka 92. stavka 2. ZJN-a.

ZJN, u članku 92. stavku 1., također omogućuje naručitelju da, po svojoj slobodnoj ocjeni, odluči hoće li tražiti od ponuditelja da pojašnjenjem ili upotpunjavanjem u vezi s dokumentima traženima sukladno člancima 67. do 74. tog Zakona ukloni pogreške, nedostatke ili nejasnoće koje se mogu ukloniti. ${ }^{60}$ Dakle, slično kao i kod regulacije vezano za neuobičajeno nisku cijenu u ponudi, navedenom zakonskom normom nije predviđena obveza opisanog postupanja naručitelja. Međutim, navesti je da se, prema aktualnoj upravnosudskoj praksi, pojašnjenje ili upotpunjavanje iz članka 92. stavka 1. i 2. ZJN-a smije odnositi isključivo na nejasnoće, manje nedostatke ili pogreške koji su otklonjivi, što ne smije imati za rezultat naknadnu zamjenu ili dostavu traženih dokumenata. ${ }^{61} \mathrm{Za}$ razliku od regulacije ZJN/07, ZJN

58 O ostalim mogućnostima koje se tiču posebnih uvjeta za izvršenje ugovora, podizvoditelja i obveza koje se odnose na poreze, zaštitu okoliša i odredbi o zaštiti radnog mjesta i na radne uvjete, vidjeti čl. 83., 84. i 86. ZJN-a.

59 Usporedi s čl. 73. ZJN/07.

60 Usporedi s čl. 51. Direktive 2004/18/EZ.

61 Ovakvo shvaćanje izrazio je Upravni sud u Rijeci u pravomoćnoj presudi broj UsI-1025/13-11 od 7. XI. 2014. 
prvi put normira mogućnost upotpunjavanja dokaza sposobnosti, dok je do sada bilo dopušteno tražiti samo njihovo pojašnjenje. ${ }^{62} 63$

U ovom dijelu ukazuje se potrebnim uputiti i na to da ZJN, u članku 93., regulira razloge za odbijanje ponude. Pritom, u stavku 1., taksativno su navedeni obligatorni razlozi, ${ }^{64}$ dok, u stavku 2., fakultativni razlozi za odbijanje ponude. U prvom slučaju naručitelj je obvezan na osnovi rezultata pregleda i ocjene ponuda ponudu odbiti, dok u drugom slučaju zakon to ostavlja naručitelju kao mogućnost. ${ }^{65}$

Pritom, ZJN, u članku 29., razlikuje i ujedno definira: 1) nepravilnu ponudu (toč. 1.), 2) neprihvatljivu ponudu (toč. 2.) te 3) neprikladnu ponudu (toč. 3.).

Tako, pod nepravilnom ponudom smatra onu koja nije izrađena u skladu s dokumentacijom za nadmetanje, sadrži odredbe koje javni naručitelj smatra štetnima ili za koju javni naručitelj osnovano smatra da nije rezultat tržišnog natjecanja, primjerice posljedica je nedopuštenog sporazuma gospodarskih subjekata.

Pod neprihvatljivom ponudom smatra onu ponudu koja zbog formalnih ili drugih objektivnih razloga ne može biti odabrana, primjerice zakašnjelo dostavljena ponuda, ponuda ponuditelja kod kojeg su stečeni razlozi za isključenje u skladu s člancima 67. i 68. ovoga Zakona, ponuda ponuditelja koji nije dokazao svoju sposobnost u skladu s dokumentacijom za nadmetanje i odredbama ovoga Zakona, ponuda kojoj nedostaje jamstvo za ozbiljnost ponude, nedopuštena alternativna ponuda, ponuda čija je cijena veća od osiguranih sredstava za nabavu, ponuda s neuobičajeno niskom cijenom.

I na kraju, pod neprikladnom ponudom podrazumijeva onu ponudu koja u cijelosti ne odgovara potrebama javnog naručitelja određenima u opisu predmeta nabave i tehničkim specifikacijama odnosno kojom se nude roba, radovi ili usluge koji očito ne zadovoljavaju potrebe javnog naručitelja u odnosu na traženi predmet nabave.

\subsection{Razlozi isključenja i uvjeti sposobnosti gospodarskih subjekata}

\subsubsection{Razlozi isključenja}

ZJN razlikuje dvije vrste razloga za isključenje gospodarskih subjekata: a) obligatorni razlozi isključenja i b) ostali (neobligatorni) razlozi za isključenje.

Obligatorni razlozi isključenja regulirani su člankom 67. ZJN-a, dok su ostali razlozi isključenja propisani člankom 68. ZJN-a. U prvom slučaju, dakle, ukoliko

62 Tako Kolar, T., Loboja, A., Vuić Z., Primjena Zakona o javnoj nabavi i novih podzakonskih propisa, Inženjerski biro, Zagreb, 2012., str. 33.

63 Usporedi s čl. 82. ZJN/07.

64 Vidjeti čl. 93. st. 1. ZJN-a.

65 Prema čl. 93. st. 2. ZJN-a javni naručitelj može (dakle, ne mora) odbiti ponudu ponuditelja koji unutar postavljenog roka nije dao zatraženo objašnjenje ili njegovo objašnjenje nije za javnog naručitelja prihvatljivo u skladu s člankom 91. ovoga Zakona. 
postoji koji od obligatornih razloga, naručitelj je dužan (mora) isključiti natjecatelja ili ponuditelja iz postupka javne nabave. S druge strane, u slučaju postojanja ostalih razloga, naručitelj može isključiti gospodarskog subjekta iz postupka javne nabave, pod uvjetom da je to naveo kao razlog za isključenje. Drugačije izneseno, ako želi koristiti jedan ili više razloga za neobligatorno isključenje gospodarskih subjekata iz postupka javne nabave, naručitelj mora prethodno, u objavi javne nabave i u dokumentaciji za nadmetanje, navesti da će ih koristiti kao razloge isključenja, u skladu s člankom 68. stavkom 2. ZJN-a. ${ }^{66}$

Obligatorni razlozi isključenja, u skladu s člankom 67. ZJN-a, tiču se: 1. postojanja pravomoćne kaznene odluke (osude) za određena kaznena djela (u odnosu na gospodarskog subjekta ili osobu ovlaštenu po zakonu za zastupanje gospodarskog subjekta), 2. neispunjenja dospjelih poreznih obveza ili obveza za mirovinsko ili zdravstveno osiguranje i 3. dostave lažnih podataka. ${ }^{67}$

Ostali razlozi isključenja, prema regulaciji članka 68. ZJN-a, obuhvaćaju četiri skupine razloga: 1) stečaj, likvidaciju, obustavu poslovne djelatnosti gospodarskog subjekta ili sličan postupak prema propisima države sjedišta gospodarskog subjekta (st. 1.), 2. postojanja pokrenutog prethodnog postupka radi utvrđivanja uvjeta za stečaj ili likvidaciju ili postupak nagodbe s vjerovnicima, ili postupak nadležnog suda za postavljanje prinudnog upravitelja nad gospodarskim subjektom (st. 2.), 3. pravomoćnu osuđivanost za kazneno djelo ili prekršaj u vezi s obavljanjem profesionalne djelatnosti (st. 3.), te, krajnje, 4. postojanje teškog profesionalnog propusta (st. 4.). ${ }^{68} 69$

U ovom dijelu valja skrenuti pozornost da ZJN, u članku 68. stavku 7., prvi put $\mathrm{u}$ legislativu sustava javne nabave uvodi definiciju teškog profesionalnog propusta. $^{70}$ Tako, zakonodavac ovaj propust u smislu stavka 1. točke 4. članka 68. definira: a) kao postupanje gospodarskog subjekta u obavljanju njegove profesionalne djelatnosti protivno odgovarajućim propisima, kolektivnim ugovorima, pravilima struke ili sklopljenim ugovorima o javnoj nabavi, a koje je takve prirode da čini tog gospodarskog subjekta neprikladnom i nepouzdanom stranom ugovora o javnoj nabavi ili okvirnog sporazuma koji javni naručitelj namjerava sklopiti te b) kod izvršenja ugovora o javnoj nabavi kao postupanje gospodarskog subjekta koje ima kao posljedicu značajne i/ili opetovane nedostatke u izvršenju bitnih zahtjeva iz ugovora koji su doveli do njegova prijevremenog raskida, nastanka štete ili drugih sličnih posljedica. ${ }^{71}$

66 Ovakvo tumačenje čl. 68. st. 2. ZJN-a „potvrđeno“ je i pravomoćnom presudom Upravnog suda u Osijeku, poslovni broj UsI-602/12-18 od 15. siječnja 2013.

67 Vidjeti pobliže čl. 67. ZJN-a.

${ }_{68}$ Pod uvjetom da je težak profesionalni propust gospodarski subjekt učinio u posljednje dvije godine do početka postupka javne nabave.

69 Vidjeti pobliže čl. 68. ZJN-a.

70 Slično bilj. 62. (Kolar i dr., 2012.), str. 32.

71 Usporedi s čl. 46. st. 2. toč. 4. ZJN/07. 


\subsubsection{Uvjeti sposobnosti}

U postupcima javne nabave javni naručitelji u skladu s člancima 70. do 74 . ZJN-a određuju uvjete sposobnosti natjecatelja ili ponuditelja (čl. 69. st. 1. ZJN-a).

Pritom, ZJN regulira tri vrste uvjeta sposobnosti: 1. pravna i poslovna sposobnost (čl. 70.), 2. financijska sposobnost (čl. 71. ZJN-a) i 3. tehnička i stručna sposobnost (čl. 72.).

Vezano za pravnu i poslovnu sposobnost, svaki natjecatelj ili ponuditelj u postupku javne nabave mora dokazati svoj upis u sudski, obrtni, strukovni ili drugi odgovarajući registar države sjedišta gospodarskog subjekta (čl. 70. st. 1.). ${ }^{72}$

Što se tiče financijske sposobnosti, odredba članka 71. stavka 1. ZJN-a, kojom su regulirani dokazi financijske sposobnosti gospodarskog subjekta u postupku javne nabave, dispozitivne je prirode. Dakle, zakonodavac je navedenom odredbom dokaze financijske sposobnosti odredio samo primjerice, a ne i taksativno (numerusclausus), čime je dopustio da javni naručitelj u pozivu na nadmetanje ili u pozivu na dostavu ponuda, kao dokaz financijske sposobnosti, odredi neki od zakonom predviđenih dokumenata ili druge dokumente koji se mogu dostaviti, uz mogućnost određivanja i starosti dokumenta. ${ }^{73}$ Drugačije kazano, ZJN je ovlastio javne naručitelje da, po svojoj slobodnoj volji, odluče hoće li odrediti uvjete financijske sposobnosti ili ne, te koje će dokaze (uključujući i njihovu starost) smatrati prikladnima za dokazivanje navedenoga uvjeta sposobnosti. ${ }^{74}$

S druge strane, za razliku od stipulacije članka 71. stavka 1. ZJN-a, odredba članka 72. stavka 3. ZJN-a, kojom su regulirani taksativno dokazi tehničke i stručne sposobnosti gospodarskog subjekta u postupku javne nabave, kogentne (prisilne) je prirode. Dakle, naručitelj može odrediti uvjete tehničke i stručne sposobnosti gospodarskog subjekta. No, ta sposobnost može se dokazivati isključivo dokazima koji su predviđeni u članku 72. stavku 3. do 5. ZJN-a. ${ }^{75}$ Svrha traženja dokaza o tehničkoj i stručnoj sposobnosti sastoji se upravo u tome da druga ugovorna strana, naručitelj potvrdi da je ponuditelj iz konkretnog postupka javne nabave već izvršio određene radove ili usluge.

\subsection{Redovna pravna zaštita}

Po pitanju redovne pravne zaštite (putem instituta žalbe), ${ }^{76}$ koja se temelji na načelima javne nabave iz članka 3., ali i na načelima zakonitosti, učinkovitosti, ekonomičnosti i kontradiktornosti, ${ }^{77} \mathrm{ZJN}$ unosi tektonske promjene i značajne novine

72 O načinu dokazivanja i dokazima pravne i poslovne sposobnosti vidjeti čl. 70. st. 2. do 5. ZJN-a.

73 Vidjeti pobliže čl. 71. st. 1. ZJN-a.

74 Slično bilj. 62. (Kolar i dr., 2012.), str. 68.

75 O načinu dokazivanja i o dokazima stručne i tehničke sposobnosti vidjeti čl. 72. st. 3. do 7. ZJN-a.

76 Prema čl. 138. st. 1. ZJN-a, za rješavanje o žalbama u vezi s postupcima sklapanja ugovora o javnoj nabavi, okvirnih sporazuma i natječaja na koje se primjenjuje ovaj Zakon nadležna je Državna komisija.

77 Prema čl. 139. st. 1. ZJN-a. 
u odnosu na dotadašnju regulaciju ZJN/07. ${ }^{78}$ Naime, ZJN uvodi, slobodno se može reći, potpuno novi koncept pravne zaštite gospodarskih subjekata u postupcima javne nabave. ${ }^{79}$

Novine se, u prvom redu, tiču: 1. (ne)postojanja prava na žalbu, 2. (načina) izjavljivanja žalbe, 3. ovlasti postupanja Državne komisije u žalbenom postupku, 4. pojma odnosno vrsta bitnih povreda, 5 . rokova za izjavljivanje žalbe, te 6 . sadržaja i učinka žalbe. ${ }^{80}$

Naime, prvo, prema pozitivnoj regulaciji, da bi postojalo pravo na izjavljivanje žalbe prema članku 141. stavku 1. ZJN-a, moraju biti kumulativno ispunjena oba uvjeta: 1 . da postoji ili da je postojao pravni interes fizičke, pravne i/ili zajednice fizičkih i/ili pravnih osoba za dobivanje određenog ugovora o javnoj nabavi ili okvirnog sporazuma, te 2 . da su te osobe pretrpjele ili bi mogle pretrpjeti štetu od navodnoga kršenja subjektivnih prava. Dakle, kumulativni uvjeti za podnošenje žalbe obuhvaćaju pravni interes za dobivanje određenog ugovora o javnoj nabavi i moguću štetu za gospodarskog subjekta. Postojanje ovog prava odnosno ispunjenje kumulativnih uvjeta za izjavljivanje žalbe na strani određenog gospodarskog subjekta ispituje Državna komisija u svakom pojedinom žalbenom postupku. S prethodnim u vezi, prema pravilima o dokazivanju sadržanima u članku 143. ZJN$\mathrm{a},{ }^{81}$ žalitelj je dužan dokazati da sudjelovanjem u konkretnom postupku javne nabave može konkurirati za dobivanje ugovora o javnoj nabavi, te da je pretrpio ili da bi mogao pretrpjeti štetu od navodnoga kršenja subjektivnih prava.

Drugo, novi koncept, za razliku od članka 145. ZJN/07, regulira da se žalba izjavljuje Državnoj komisiji, s time da se primjerak žalbe dostavlja naručitelju istodobno s dostavljanjem žalbe komisiji (čl. 145. st. 1. do 3. ZJN-a).

Treće, vezano za ovlasti i granice postupanja u žalbenom postupku, shodno članku 144. stavku 1. ZJN-a, Državna komisija postupa u granicama žalbenih navoda, a po službenoj dužnosti pazi na bitne povrede koje su počinjene u fazi postupka $u$ kojoj je izjavljena žalba sukladno člancima 146. do 153. ovoga Zakona. Dakle, bitna novota ogleda se u tome da Državna komisija pazi po službenoj dužnosti samo na bitne povrede koje su počinjene u stadiju postupka u kojoj je izjavljena žalba sukladno člancima 146. do 153 . ZJN-a. ${ }^{82}$ Primjerice, žalitelj je prekludiran osporavati zakonitost dokumentacije za nadmetanje nakon proteka zakonskih rokova za izjavljivanje takve žalbe a u stadiju postupka u kojem je izjavljena žalba protiv odluke o odabiru. 161.

78 Pravna zaštita putem žalbe po ZJN/07 bila je regulirana u Glavi 5. „Pravna zaštita“, u čl. 134. do

79 Tako Ibidem bilj. 62. (Kolar i dr., 2012.), str. 42.

80 Slično Ibidem bilj. 62. (Kolar i dr., 2012.), str. 42-47.

81 Vidjeti čl. 143. ZJN-a.

82 Prema dotadašnjem uređenju pravne zaštite iz čl. 141. st. 1. ZJN/07 Državna komisija postupala je po službenoj dužnosti u odnosu na bitne povrede neovisno o tome na koji je dio postupka javne nabave žalba izjavljena. 
Četvrto, ZJN, u članku 144. stavku 2., po pitanju pojma i vrsta bitnih povreda, u odnosu na regulaciju članka 140 . ZJN/07-a, predviđa samo jednu bitnu povredu. Bitna povreda postoji ako naručitelj nije primijenio ili je nepravilno primijenio koju odredbu izvora prava, što je bilo od utjecaja na zakonitost postupka, a za koju žalitelj nije znao niti mogao znati u trenutku izjavljivanja žalbe. ${ }^{83}$

Peto, poboljšanoj učinkovitosti pravne zaštite pridonijet će i izmjene vremenskih okvira za ulaganje žalbe na određene stadije postupka, s time da će se, primjerice, na dokumentaciju za nadmetanje žalba moći izjaviti u roku od deset dana (nabava velike vrijednosti) odnosno pet dana (nabava male vrijednosti) od dana objave poziva na nadmetanje i dokumentacije, a ne kao do sada tek nakon otvaranja ponuda. ${ }^{84}$ Time će se nepravilnosti uočene u određenim stadijima postupka uklanjati brže i učinkovitije, a, s druge strane, omogućiti da se izmjena nezakonite dokumentacije za nadmetanje ispravi prije otvaranja ponuda..$^{85} 86$

Šesto, u pogledu obvezatnog sadržaja žalbe, umjesto ranijeg (neodređenog) dokaza o uplati naknade, zakonodavac, u članku 159. stavku 1. točki 9. ZJN-a, pobliže definira što se smatra dokazom o plaćanju naknade za pokretanje žalbenog postupka. Tako se ovim dokazom podrazumijeva onaj na temelju kojeg se može utvrditi da je transakcija izvršena, pri čemu se dokazom smatraju i neovjerene preslike ili ispisi provedenih naloga za plaćanje, uključujući $i$ onih izdanih u elektroničkom obliku osim u slučaju iz članka 169. stavka 6. ovoga Zakona. S tim u vezi, umjesto ranijeg inzistiranja na dokazu o uplati naknade, koji je isključivo dužan podastrijeti žalitelj (uplatitelj), novim konceptom određenim u članku 169. stavku 5. ZJN-a, naglasak je stavljen na primarnu obvezu Državne komisije da provjeri izvršenje uplate naknade, dok teret dokazivanja uplate naknade na uplatitelju leži tek sekundarno.

Daljnja novost koju donosi ZJN ogleda se u suspenzivnosti učinka žalbe na dokumentaciju za nadmetanje ili izmjenu dokumentacije za nadmetanje, kako u otvorenom postupku javne nabave, tako i u ograničenom, pregovaračkom postupku s prethodnom objavom i u natjecateljskom dijalogu ${ }^{87}$ Naime, prema članku 157. stavku 1. i članku 158. stavku 1 . ZJN-a, u slučaju izjavljivanja žalbe na dokumentaciju za nadmetanje ili izmjenu dokumentacije za nadmetanje, naručitelj je dužan, po primitku žalbe, obavijestiti zainteresirane subjekte da je izjavljena takva žalba i da se zaustavlja postupak javne nabave.

K tome, uzimajući u usporedbu s regulacijom članka 159. ZJN/07, ZJN značajno povisuje naknadu za pokretanje žalbenog postupka, na koji način stavlja u otegotan položaj potencijalnog žalitelja. S tim u vezi, po ocjeni autora, opravdano se može postaviti pitanje je li ovakav način regulacije (odnosno zakonom određeni (previsoki) iznosi naknade koje su žalitelji dužni podmiriti istovremeno s izjavljivanjem žalbe)

83 Usporedi s čl. 140. ZJN/07.

84 Ibidem bilj. 62. (Kolar i dr., 2012.), str. 44.

85 Ibidem.

86 Usporedi s dotadašnjom regulacijom iz čl. 147. st. 2. ZJN/07.

87 Slično Ibidem bilj. 62. (Kolar i dr., 2012.), str. 45. 
bitno narušio Ustavom zajamčeno pravo na žalbu.$^{88}$ Naime, legitimna svrha Zakona o Državnoj komisiji, ali i svrha uređivanja pravila žalbenog postupka odredbama ZJN-a sastoji se u ustrojavanju učinkovitog državnog tijela koje će, kroz žalbene postupke, nadzirati procese javne nabave koje provode različite pravne osobe, radi sprečavanja manipulacija i nepravilnosti koje se u takvim procesima događaju. ${ }^{89}$ Nadzor nad bilo kojim postupkom, pa i nad postupkom javne nabave, podrazumijeva stvarnu mogućnost da se zainteresirani subjekt obrati tijelu nadležnom za nadzor, izloži svoje prigovore te da to tijelo meritorno razmotri njegovu argumentaciju i utvrdi činjenice o navodnim nepravilnostima. Provedba nadzora podrazumijeva, dakle, prije svega, pristup nadzornom tijelu i osiguranje prava na učinkovitu žalbu što je bez sumnje ustavno postupovno jamstvo te ulazi u širi korpus postupovnih jamstava pravičnog suđenja (odlučivanja) koja proizlaze iz članka 29. stavka 1. Ustava. ${ }^{90} 919293$

\subsection{Troškovi žalbenog postupka}

Regulacija troškova žalbenog postupka sadržana je u članku 170. ZJN-a.

Prema odredbama navedenog članka, o troškovima odlučuje Državna komisija prema ishodu žalbenog postupka i uspjehu žalitelja žalbom. Važno je naglasiti da se u žalbenom postupku strankama nadoknađuju samo opravdani troškovi. Pritom, zakonodavac ne određuje pobliže koji su to opravdani troškovi, već je to prepušteno ocjeni Državne komisije odnosno upravnim sudovima u svakom pojedinom predmetu.

U ovom dijelu zakonodavac posebno regulira pitanje naknade troškova žalbenog postupka u slučaju: a) odustajanja od žalbe, odbijanja ili odbacivanja žalbe, kada žalitelj nema pravo na naknadu troškova (čl. 170. st. 4. ZJN-a), b) djelomičnog usvajanja žalbe, kada Državna komisija može odlučiti da svaka stranka snosi svoje troškove, da se troškovi žalbenog postupka podijele na jednake dijelove ili da se podijele razmjerno usvajanju žalbe (čl. 170. st. 5. ZJN-a) i c) usvajanja žalbe (dakle, usvajanja žalbe u cijelosti), kada će Državna komisija svojom odlukom naložiti

88 Vidjeti čl. 18. st. 1. Ustava.

89 Iz odluke Ustavnog suda poslovni broj U-III-4885/2012 od 3. srpnja 2014. (dostupna na: www. usud.hr).

90 Ibidem.

91 Pravo na pravično suđenje, koje u sebi obuhvaća i pravo na pristup „sudu“ (javnopravnom tijelu), najvažnije je procesno ljudsko pravo, koje je u hrvatskom pravnom sustavu ugrađeno na ustavnoj $i$ zakonskoj razini na temelju čl. 6. st. 1. Konvencije za zaštitu ljudskih prava s protokolima 1, 4, 6, 7, 11, 12, 13 i 14, koja je u primjeni od 6. studenog 1997. godine (NN-MU, br. 18/97, 6/99, 8/99 - ispravak, 14/02, 13/03, 9/05, 1/06 i 2/10).

92 O pravu na pravično suđenje u europskoj sudskoj praksi vidjeti i Šarin, D., „Pravo na pristup sudu u praksi Europskog suda za ljudska prava“, Pravni vjesnik, Zagreb, 2015., str. 267-296.

93 O pravu na pravično suđenje u praksi Europskog suda za ljudska prava i njezinu utjecaju na hrvatsko pravo i praksu vidjeti Uzelac, A., Pravo na pravično suđenje u građanskim predmetima: nova praksa Europskog suda za ljudska prava i njen utjecaj na hrvatsko pravo $i$ praksu, Pravni fakultet Sveučilišta u Zagrebu, Zagreb, 2010., str. 101-148. 
naručitelju plaćanje troškova žalbenog postupka žalitelju u roku od 8 dana od dana primitka odluke Državne komisije (čl. 170. st. 6. ZJN-a).

\section{JAVNA NABAVA U AKTUALNOJ UPRAVNOSUDSKOJ PRAKSI}

\subsection{Uvodno}

U svrhu potpunijeg pristupa predmetnoj materiji, od strane autora provedeno je empirijsko istraživanje, koje je bilo podijeljeno u dva temeljna djela.

Prvi dio odnosi se na analizu statističkih podataka iz službenih statistika o radu Visokog upravnog suda Republike Hrvatske ${ }^{94} \mathrm{i}$ upravnih sudova u Splitu, ${ }^{95}$ Zagrebu,

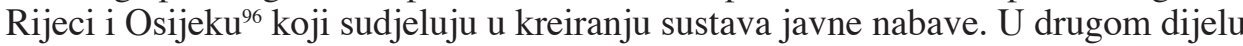
analizirane se pravomoćne odluke upravnih sudova donesene u predmetima javne nabave. Istraživanje je provedeno na cijelom području Republike Hrvatske prema namjernom uzorku za razdoblje od 1. siječnja 2012. godine do 30. lipnja 2016. godine.

Analizom podataka iz službenih statistika istražen je broj pokrenutih, riješenih i (ostalo) neriješenih predmeta javne nabave, zastupljenost ovih vrsta predmeta u ukupnom prilivu svih upravnih sporova te struktura pravomoćnih odluka. S druge strane, analizom pravomoćnih odluka prikazane su i analizirane dvojbe proizišle iz prakse, pravna shvaćanja i, krajnje, temeljne značajke aktualne upravnosudske prakse u ovim vrstama postupaka. ${ }^{97}$ Nakon provedenog istraživanja, provedena je statistička obrada podataka.

Smatramo da će rezultati istraživanja biti od krucijalne važnosti i dostatni za provjeru u radu postavljenih hipoteza, kako glede upravnosudske prakse, tako i normativne regulacije sustava javne nabave.

94 Statistički podaci, izneseni u ovom radu o praksi Visokog upravnog suda u predmetima javne nabave, autoru su predani dopisom tajništva tog suda, poslovni broj 9 Su-311/2016-2 od 1. srpnja 2016. koji je zaprimljen u Upravnom sudu u Splitu 6. srpnja 2016., s time da su isti dopunjeni putem e-pošte 25. kolovoza 2016.

95 Statistički podaci, izneseni u ovom radu o praksi Upravnog suda u Splitu u predmetima javne nabave, autoru su predani neposredno i putem e-pošte 29. lipnja 2016. od strane sudske pisarnice tog suda.

96 Statistički podaci, izneseni u ovom radu o praksi upravnih sudova u Zagrebu, Rijeci i Osijeku u predmetima javne nabave, autoru su predani elektroničkim putem (e-pošte) tijekom srpnja i kolovoza 2016. od strane sudskih pisarnica Upravnog suda u Zagrebu, Upravnog suda u Rijeci i Upravnog suda u Osijeku.

97 Nakon analize pravomoćnih odluka upravnih sudova, od strane autora su sačinjene ukupno 93 sentence. 


\subsection{Službene statistike}

Što se tiče postupanja upravnih sudova prvog stupnja u sporovima javne nabave, u razdoblju od 1. siječnja 2012. godine do 30. lipnja 2016. godine pokrenuto je 738 takvih upravnih sporova, od čega 444 ili 60,16 \% u Upravnom sudu u Zagrebu, 126 ili 17,07 \% u Splitu, 76 ili 10,30 \% u Osijeku i 92 ili 12,47 \% u Rijeci. Pritom, u VUSRH je zaprimljeno 79 žalbenih predmeta iz upisnika Usž vezano za postupke javne nabave. Dakle, u promatranom razdoblju u upravnoj grani sudovanja sveukupno je zaprimljeno 817 takvih predmeta.

$\mathrm{U}$ istom razdoblju u prvom stupnju riješeno je 527 predmeta javne nabave, od čega je Upravni sud u Zagrebu riješio 314 ili 59,58 \%, Upravni sud u Splitu 90 ili 17,08 \%, Upravni sud u Osijeku 58 ili 11,01 \%, a u Upravnom sudu u Rijeci 65 ili $12,33 \%$, uzimajući u odnos broj riješenih i ukupno riješenih takvih predmeta. Pritom, u drugom stupnju, kada govorimo o predmetima javne nabave, riješena su ukupno 63 žalbena predmeta.

Na kraju promatranog razdoblja, odnosno na 30. lipnja 2016. godine ostalo je neriješeno ukupno 227 predmeta javne nabave, od čega 211 na prvom stupnju, a 16 na drugom stupnju upravnog sudovanja. Vezano za rad upravnih sudova, u Zagrebu je ostalo neriješeno tih vrsta sporova 130, u Splitu 36, u Osijeku 18, u Rijeci 27, a pri VUSRH-u 16 predmeta.

Stavljajući u odnos prema ukupno primljenim svim vrstama upravnih predmeta bez UrI spisa, zastupljenost predmeta javne nabave u promatranom razdoblju kreće se u rasponu od 0,98 \% u Upravnom sudu u Splitu do 2,09 \% u Upravnom sudu u Zagrebu. Dotle, udio predmeta javne nabave u ukupnom broju zaprimljenih žalbenih predmeta iz upisnika Usž (ukupno 6674) pri VUSRH-u iznosi 1,19\%.

Sagledavajući strukturu odluka upravnih sudova u okviru nadzora rada uprave u postupcima javne nabave, prema pribavljenim i obrađenim statističkim podacima, ukupno je potvrđeno (odbijen tužbeni zahtjev) 265 ili 50,28 \% odluka javnopravnog tijela, poništeno 95 ili $18,03 \%$, s time da je upravni spor riješen na ini način (odbačena tužba, obustavljen spor, nenadležnost i dr.) u 167 ili 31,69 \% predmeta.

Što se tiče strukture odluka VUSRH-a po žalbama izjavljenima protiv odluka prvostupanjskih upravnih sudova, potvrđeno je 38 ili $60,32 \%$ odluka, preinačeno 0 ili $0 \%$, a ukinute 3 ili $4,76 \%$ uzimajući u obzir ukupno 63 donesene drugostupanjske odluke. Pritom, na ini način su riješena ukupno 22 ili 34,92 \% žalbena predmeta.

I najzad, ukupno 31 (trideset jedan) sudac upravnih sudova postupa u predmetima javne nabave, od čega 7 (sedam) sudaca u 2 (dva) vijeća pri VUSRH-u, a 24 (dvadeset četiri) prvostupanjska suca. Zanimljivo je iznijeti da u upravnim sudovima u Zagrebu i Osijeku svi suci tih sudova postupaju u predmetima javne nabave, dok u Upravnom sudu u Splitu i Upravnom sudu u Rijeci po 2 (dva) suca. Zaključiti je da su u upravnim sudovima u Splitu i Rijeci, za razliku od sudova u Zagrebu i Osijeku, predsjednici sudova proveli specijalizaciju rada prema srodnim upravnim područjima, što će zasigurno doprinijeti unapređenju rada i učinkovitosti suda u rješavanju predmeta te krajnje smanjiti broj neriješenih predmeta. 
U cilju bolje preglednosti, obrađeni statistički podaci o radu upravnih sudova u promatranom razdoblju iznose se u tabličnom i grafikonskom prikazu.

Tablica 1. - Broj primljenih, riješenih i (ostalo) neriješenih upravnih sporova radi javne nabave u ukupnoj strukturi zaprimljenih, uz broj sudaca upravnih sudova koji postupaju u tim vrstama sporova za razdoblje od 1. siječnja 2012. do 30. lipnja 2016.

\begin{tabular}{|c|c|c|c|c|c|}
\hline \multirow{2}{*}{$\begin{array}{l}\text { UPRAVNI } \\
\text { SUDOVI }\end{array}$} & \multirow[t]{2}{*}{ PRIMLJENO } & \multicolumn{4}{|c|}{ RIJEŠENO } \\
\hline & & $\begin{array}{c}\text { potvrđena } \\
\text { odluka }\end{array}$ & $\begin{array}{l}\text { preinačena } \\
\text { odluka }\end{array}$ & $\begin{array}{l}\text { ukinuta } \\
\text { odluka }\end{array}$ & $\underset{\text { načini }}{\text { INI }}$ \\
\hline \multirow[t]{2}{*}{ VUSRH } & 79 & 38 & $\mathbf{0}$ & 3 & 22 \\
\hline & & $\begin{array}{l}\text { usvojen } \\
\text { tužbeni } \\
\text { zahtjev }\end{array}$ & $\begin{array}{c}\text { odbijen tužbeni } \\
\text { zahtjev }\end{array}$ & \multicolumn{2}{|c|}{$\begin{array}{c}\text { INI način } \\
\text { (odbačaj tužbe, } \\
\text { obustava i dr.) }\end{array}$} \\
\hline US Zagreb & 444 & 51 & 157 & \multicolumn{2}{|c|}{106} \\
\hline US Split & 126 & 19 & 33 & \multicolumn{2}{|c|}{38} \\
\hline US Osijek & 76 & 16 & 41 & \multicolumn{2}{|c|}{1} \\
\hline US Rijeka & 92 & 9 & 34 & \multicolumn{2}{|c|}{22} \\
\hline \multirow{2}{*}{ UKUPNO: } & \multirow{2}{*}{817} & 95 & 265 & \multicolumn{2}{|c|}{167} \\
\hline & & \multicolumn{4}{|c|}{527} \\
\hline
\end{tabular}




\begin{tabular}{|c|c|c|}
\hline $\begin{array}{c}\text { OSTALO } \\
\text { NERIJEŠENO }\end{array}$ & ZASTUPLJENOST & BROJ SUDACA \\
\hline 16 & $\begin{array}{c}1,19 \% \\
(79 / 6674)\end{array}$ & 7 (dva vijeća) \\
\hline 130 & $\begin{array}{c}2,09 \% \\
(444 / 21254)\end{array}$ & 13 \\
\hline 36 & $\begin{array}{c}0,99 \% \\
(126 / 12742)\end{array}$ & 2 \\
\hline 18 & $\begin{array}{c}1,01 \% \\
(76 / 7531)\end{array}$ & 7 \\
\hline 27 & $\begin{array}{c}1,02 \% \\
(92 / 9044)\end{array}$ & 2 \\
\hline $227(221 / 16)$ & u rasponu od $0,99 \%$ do $2,09 \%$ & 31 \\
\hline
\end{tabular}

„Napomena: u stupcu 2. „Primljeno“, kod VUSRH, naveden je broj zaprimljenih žalbenih predmeta iz upisnika Usž; u stupcu 5. „Zastupljenost“ podrazumijeva se ukupno predmeta javne nabave u odnosu na broj ukupno primljenih svih vrsta upravnih sporova.

Analizirajući izloženo, zaključiti je da je zanemariv udio predmeta javne nabave u ukupnom broju zaprimljenih upravnih sporova. To bi, nadalje, ukoliko bismo uzeli samo kriterij apsolutnog broja, na prvi pogled, upućivalo na (pogrešan) zaključak da je upravnosudska praksa, kao izvor prava, zanemarivo sudjelovala u kreiranju normativne i praktične politike po pitanju javne nabave.

Cijeneći iznesene statističke parametre o radu upravnih sudova i sadržaj Izvješća o radu Državne komisije za kontrolu postupaka javne nabave za 2012., 2013. i 2014. godinu, posebno u dijelu broja primljenih, riješenih i ostalo neriješenih žalbenih 
predmeta, ${ }^{98}$ aktualnu upravnosudsku praksu kao izvora prava, kada govorimo o predmetima javne nabave, obilježilo je nekoliko temeljnih značajki: fragmentarnost, s obzirom na to da je mali broj odluka javnopravnog tijela uopće osporavan pred upravnim sudovima, te nepotpunost, jer značajan broj odluka prvostupanjskih upravnih sudova nije podvrgnut ocjeni zakonitosti u žalbenom postupku.

Izneseni zaključci potvrđeni su i idućim statistikama vezano za: strukturu odluka VUSRH-a po žalbama protiv odluka prvostupanjskih upravnih sudova; strukturu odluka upravnih sudova u okviru nadzora rada Državne komisije te za pravnu zaštitu od odluka prvostupanjskih upravnih sudova.

Grafikon 1. - Struktura odluka upravnih sudova u okviru nadzora rada javnopravnih tijela u postupcima javne nabave u razdoblju od 1. siječnja 2012. do 30. lipnja 2016.

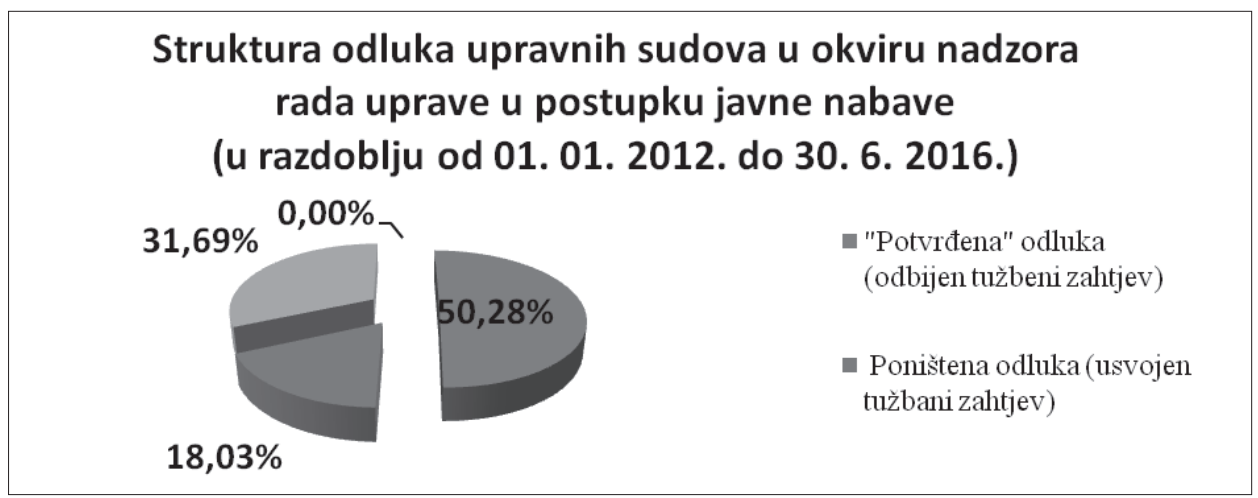

Što se tiče upravnosudskog nadzora zakonitosti rada uprave u postupcima javne nabave, sagledavajući izložene podatke, u promatranom razdoblju u približno polovici upravnih sporova ,potvrđena“ je odluka, odnosno odbijen tužbeni zahtjev, dok je u $18,03 \%$ slučajeva odluka javnopravnog tijela poništena i predmet vraćen na ponovni postupak. Pritom, u gotovo $32 \%$ slučajeva upravni spor nije završio meritornom odlukom, već je riješen na ini način, bilo da je tužba odbačena, spor obustavljen ili da se upravni sud oglasio nenadležnim. S obzirom na vrlo „mali“ uzorak, odnosno broj pokrenutih upravnih sporova u kojima su stranke tražile sudsku zaštitu od odluka javnopravnog tijela u predmetima javne nabave, obrađeni statistički podaci možda nisu dostatni kako bi se provela sveobuhvatna analiza i sa sigurnošću (u) tvrdila visoka razina profesionalnosti, stručnosti i kvalitete rada službenih osoba javnopravnih tijela koji postupaju u postupcima javne nabave.

98 Izvješća dostupno na: www.dkom.hr/default.aspx?id=25. Prema tim izvješćima, ukupno je tijekom 2014. godine pred Državnom komisijom bilo 1512 žalbenih predmeta, s time da je iz 2013. preneseno 197 neriješenih predmeta, a u 2014. zaprimljeno 1315 žalbi. Pritom, tijekom 2014. riješeno je ukupno 1200 predmeta. Iznoseći o 2013. godini, zaprimljeno je ukupno 2135 žalbi, a riješeno 2101 predmeta. Dotle, sagledavajući 2012., zaprimljeno je 1728 žalbenih predmeta, a riješeno ukupno 1867 predmeta. 
Naime, u razdoblju od 1. siječnja 2012. do 30. lipnja 2016. ukupno je pokrenuto 738 upravnih sporova, dok je, prema raspoloživim podacima, u razdoblju od početka 2012. do kraja 2014. pred Državnom komisijom ukupno zaprimljeno 5178 ili godišnje prosječno 1726 žalbenih predmeta.

U pogledu strukture odluka Visokog upravnog suda u predmetima iz upisnika Usž, odnosno po žalbama protiv odluka upravnih sudova prvog stupnja, u razdoblju od 1. siječnja 2012. godine do 30. lipnja 2016. godine, uzimajući u obzir ukupno riješena 63 žalbena predmeta koji su se vodili radi javne nabave, od strane višeg suda potvrđeno je 38 ili 60,32 \% odluka (dakle, odbijena je žalba kao neosnovana), preinačeno je 0 ili $0 \%$ odluka, dok su poništene 3 ili 4,76 \% odluka. Pritom, na ini način riješena su 22 ili 34,92 \% predmeta (npr. odbačaj žalbe, obustava žalbenog postupka i dr.).

Grafikon 2. - Struktura odluka VUSRH-a po žalbama protiv odluka prvostupanjskih upravnih sudova (predmeti iz upisnika Uš̌) u razdoblju od 1. siječnja 2012. godine do 30. lipnja 2016.

Prikazani statistički parametri potvrđuju jednu od hipoteza da je Visoki

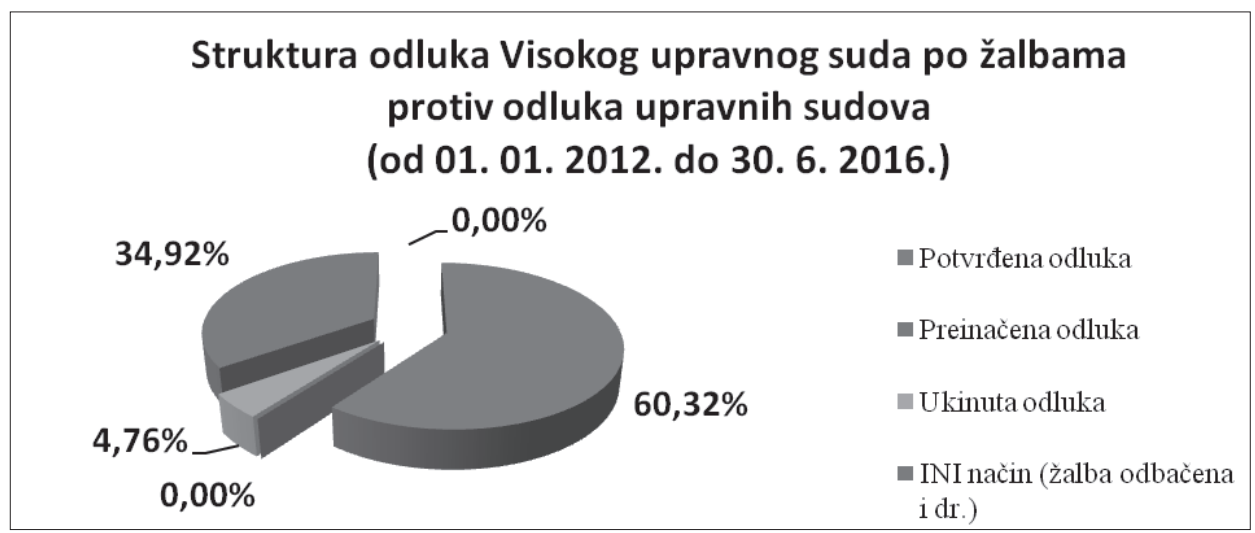

upravni sud u novijoj upravnosudskoj praksi imao zanemarivu ulogu u kreiranju upravnopravne i upravnosudske prakse po pitanju javne nabave, s obzirom na to da je u četveroipolgodišnjem razdoblju donio svega 41 meritornu odluku, ako imamo u vidu broj pokrenutih upravnih sporova, donesenih odluka upravnih sudova prvog stupnja i broj žalbenih predmeta koji su zaprimljeni pred Državnom komisijom u razdoblju od početka 2012. do kraja 2014. godine prema ranije navedenim godišnjim izvješćima o radu. Utoliko, slobodno se može reći da VUSRH nije ispunio svoju temeljnu ulogu u vidu ujednačavanja prakse i primjene prava u predmetima javne 
nabave, što je posljedica, u prvom redu, loše zakonodavne politike i normativne regulacije upravnog spora čije je donošenje u nadležnosti zakonodavne vlasti. ${ }^{99}$

Potonje izneseno proizlazi i iz sljedećeg grafikonskog prikaza vezano za korištenu redovnu pravnu zaštitu od odluka upravnih sudova. Naime, uzimajući u obzir broj zaprimljenih žalbenih predmeta (79) i broj ukupno donesenih odluka pred prvostupanjskim sudovima (527), u promatranom razdoblju je u samo 14,99 $\%$ slučajeva pokrenut žalbeni postupak pred VUSRH-om, dok u 85,01 \% slučajeva stranka nije zatražila redovnu pravnu zaštitu, bilo da žalba nije bila dopuštena, bilo da žalba nije bila izjavljena iako je bila dopuštena.

Grafikon 3. - Redovna pravna zaštita od odluka prvostupanjskih upravnih sudova u razdoblju od 1. siječnja 2012. do 30. lipnja 2016.

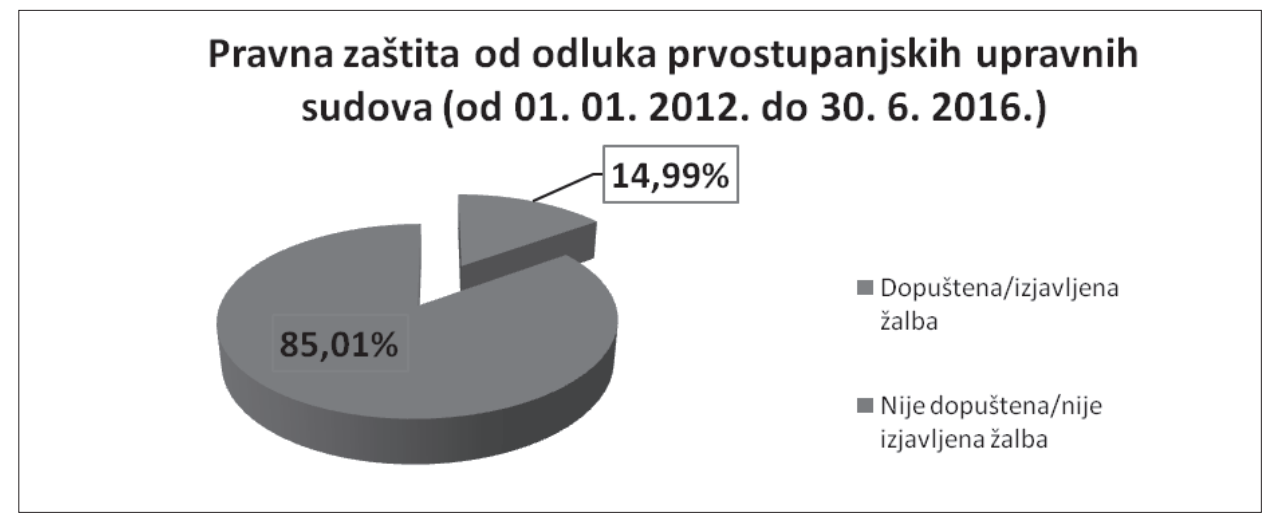

\subsection{Aktualna upravnosudska praksa - dvojbe i zauzeta pravna shvaćanja}

Analizom pravomoćnih odluka upravnih sudova u razdoblju primjene ZUS-a, sublimirano izneseno, u praksi sporni aspekti sustava javne nabave tiču se prvenstveno dvojbi po pitanju: 1) mjesne nadležnosti upravnih sudova u predmetima javne nabave, 2) (ne)poštovanja temeljnih načela javne nabave, 3 ) tko bi bili obveznici primjene ZJN-a, 4) razloga isključenja gospodarskih subjekata iz postupaka javne nabave, 5) uvjeta sposobnosti gospodarskih subjekata, 6) sadržaja, načina izrade i postupanja s dokumentacijom za nadmetanje, 7) sadržaja, načina izrade i postupanja s pristiglim ponudama, 8) pravne zaštite te 9) naknade troškova žalbenog postupka. Isto tako, zabilježen je značajan broj slučajeva u kojima se Državna komisija u

99 Prema Ustavu, Hrvatski je sabor predstavničko tijelo građana i nositelj zakonodavne vlasti u Republici Hrvatskoj (čl. 70.), a zakone donosi Hrvatski sabor (čl. 80. st. 1. podst. 2.). 
ponovnom postupku, u izvršenju pravomoćnih presuda, nije pridržavala pravnih shvaćanja i primjedaba upravnoga suda. ${ }^{100}$

Što se tiče mjesne nadležnosti, pojavile se se dvojbe vezano za kriterij prema kojem se određuje mjesna nadležnost upravnih sudova u upravnim sporovima koji se odnose na postupke javne nabave, te kriterij prema kojem se određuje mjesna nadležnost u postupku javne nabave u kojem je predmet upravnog spora ocjena zakonitosti samo onog dijela pojedinačne odluke kojim je odlučeno o troškovima žalbenog postupka.

Glede nepoštovanja temeljnih načela javne nabave pojavile su se dvojbe o interpretaciji (tumačenju) prvenstveno načela razmjernosti, jednakog tretmana i zabrane diskriminacije.

„Raspravljajući” o razlozima isključenja gospodarskih subjekata, razlučene su dvojbe koje su se ticale: a) obligatornih razloga isključenja iz članka 67 . ZJN-a i b) ostalih razloga za isključenje iz članka 68 . ZJN-a. Kod obligatornih razloga isključenja ukazale su se dvojbe vezano za: a) formu izjave o nekažnjavanju (čl. 67. st. 3. toč. 3. ZJN-a) i b) (obvezatan) sadržaj izjave o nekažnjavanju (čl. 67. st. 1. toč. 1. i st. 3. toč. 3. ZJN-a), a kod ostalih razloga isključenja dvojbe vezano za: a) (ne) postojanje teškog profesionalnog propusta (čl. 68. st. 7. ZJN-a), b) dokazivanje (ne) postojanja teškog profesionalnog propusta (teret dokaza), c) mogućnost korištenja jednog ili više razloga za neobligatorno isključenje gospodarskih subjekata od strane naručitelja, te d) tumačenje čl. 68. st. 1. toč. 1. i 2. ZJN-a i, s tim u vezi, predstavlja li predstečajna nagodba razlog za isključenje.

Vezeno za uvjete sposobnosti gospodarskih subjekata, najviše dvojbi javilo se po pitanju: a) pravne i poslovne sposobnosti iz članka 70 . ZJN-a i b) financijske sposobnosti iz članka 71. ZJN-a (ali i u određenom manjem dijelu vezano za tehničku i stručnu sposobnost te primjenu čl. 72 . ZJN-a). Što se tiče pravne $i$ poslovne sposobnosti, ukazalo se dvojbenim: a) kojim dokazima se dokazuje pravna i poslovna sposobnost gospodarskih subjekata u postupku javne nabave loživa ulja za osnovne škole, b) mora li gospodarski subjekt koji obavlja djelatnost servisiranja i isključivanja iz uporabe proizvoda odnosno uređaja za hlađenje i klimatizaciju imati dozvolu iz čl. 27. st. 1. Uredbe o tvarima koje oštećuju ozonski sloj (NN, br. 120/05) te c) dokazivanje pravne i poslovne sposobnosti zajednice ponuditelja. U vezi s financijskom sposobnosti pojavile su se dvojbe o: a) pravnoj prirodi odredbe članka 71. stavka 1 . ZJN-a, b) trenutku ocjenjivanja financijske (ne) sposobnosti pojedinih gospodarskih subjekata, c) vrsti i starosti dokaza financijske sposobnosti, d) načinu određivanja dokaza financijske sposobnosti u dokumentaciji za nadmetanje te e) dokazivanju financijske sposobnosti zajednice ponuditelja. I krajnje, u pogledu stručne i tehničke sposobnosti pojavile su se dvojbe vezano za:

100 Radi se o pravomoćnim prvostupanjskim presudama broj UsI-1259/12 (sud u Splitu, od 22. I. 2013.), UsI-1887/13-8 (sud u Splitu od 15. I. 2014.), UsI-2219/12 (sud u Splitu, od 11. IX. 2014.), UsI1186/12-23 (sud u Rijeci, od 21. II. 2014.), UsI-907/12-5 (sud u Osijeku, od 5. VI. 2013.), UsI-966/13-11 (sud u Osijeku, od 4. IV. 2014.), UsI-780/13-19 (sud u Osijeku, od 15. I. 2014.), UsI-437/13-18 (sud u Osijeku, od 23. XII. 2013.) i UsI-494/14-15 (sud u Rijeci, od 22. V. 2015.) i presudi VUSRH-a broj Usž1213/15-2 od 1. X. 2015. 
a) pravnu prirodu odredbe članka 72 . ZJN-a i b) svrhu traženja dokaza o stručnoj i tehničkoj sposobnosti gospodarskog subjekta.

U tumačenju odredbi kojima je regulirana dokumentacija za nadmetanje, pojavile su se, u prvom redu, dvojbe glede: a) (obvezatnog) sadržaja dokumentacije za nadmetanje, b) određivanja i opisa predmeta nabave i c) tehničkih specifikacija (čl. 81. ZJN), a u tumačenju odredbi kojima su regulirani sadržaj, način izrade i postupanje s pristiglim ponudama, dvojbe vezano za: a) formu i obvezatan sadržaj ponude, b) iskazivanje popusta na cijenu u troškovniku, c) ispravak ponude, d) (ne) usklađenost ponude s dokumentacijom za nadmetanje, e) postupanje s ponudom $\mathrm{u}$ kojoj je iskazana neuobičajeno niska cijena (čl. 91. ZJN-a) i f) primjenu članka 92. ZJN-a kojim je uređeno pojašnjenje i upotpunjavanje ponude.

Što se tiče pravne zaštite, ukazale su se dvojbe o: a) nadležnosti Državne komisije za rješavanje žalbi (čl. 138. ZJN-a), b) (ne)postojanju prava na žalbu, u smislu čl. 141. ZJN-a, c) obvezatnom sadržaju žalbe, d) (ne)urednosti žalbe, e) (ne) pravodobnosti žalbe, f) (granicama) ovlasti Državne komisije u žalbenom postupku (čl. 144. ZJN-a) i g) sadržaju odluke Državne komisije (čl. 164. ZJN-a).

I najzad, odlučujući o naknadi troškova žalbenog postupka, ukazalo se spornim: a) je li vrijednost predmeta spora u postupku javne nabave (ne)procjenjiva, b) što predstavlja vrijednost predmeta spora u postupku javne nabave, c) koji se troškovi imaju smatrati opravdanima, u smislu članka 170. stavka 3. ZJN-a, d) ima li žalitelj pravo na naknadu cjelokupnog troška postupka u slučaju kada je u cijelosti uspio žalbom, a u uvjetima kada svi žalbeni navodi nisu ocijenjeni osnovanima, te e) primjena odredbe čl. 170. st. 5. ZJN-a u slučaju djelomičnog uspjeha žalitelja žalbom.

Neke od izloženih dvojbi nisu se odnosile na važeći normativni okvir pravnog uređenja sustava javne nabave, ali, po ocjeni autora, mogu biti aktualne i korisne za primjenjivače propisa, poglavito suce upravnih sudova, koji, u pravilu, postupajući u dodijeljenim predmetima i dalje moraju tumačiti „stare“ (nevažeće) propise, s obzirom na postojeći dvostupanjski upravni postupak i dvostupanjski upravni spor, učestale normative promjene te prosječne rokove rješavanja upravnih sporova. Štoviše, cijeneći da ZJN sadrži pojedine odredbe koje su gotove istovjetne dotadašnjoj regulaciji ZJN/07, zauzeta pravna shvaćanja u vezi s primjenom nevažećih normativa mogu biti korisna te primjenjiva i prilikom tumačenja važeće zakonske regulacije sustava javne nabave.

\subsubsection{O sukobu mjesne nadležnosti upravnih sudova}

Svoj rad po pitanju aktualne upravnosudske prakse u postupcima javne nabave započet ću s dvije odluke Visokog upravnog suda Republike Hrvatske, ${ }^{101}$ koje su donesene u postupku odlučivanja o sukobu mjesne nadležnosti upravnih sudova, za što nadležnost visokog suda proizlazi iz članka 12. stavka 3. točke 3. ZUS-a. U

101 U daljnjem tekstu: Visoki upravni sud. 
prvom slučaju, ${ }^{102}$ Visoki je upravni sud zauzeo pravno shvaćanje da se u upravnim sporovima koji se odnose na postupke javne nabave mjesna nadležnost određuje prema kriteriju predmeta spora, na način da je mjesno nadležan onaj upravni sud na području kojega naručitelj ima sjedište na temelju odredbe članka 13. stavka 4. ZUS-a, a ne prema općem kriteriju. U drugom slučaju, ${ }^{103}$ kada je predmet spora bila ocjena zakonitosti samo onog dijela pojedinačne odluke kojim je javnopravno tijelo odlučilo o pravu stranke na naknadu troškova žalbenog postupka, sud je smatrao da se mjesna nadležnost određuje prema općem kriteriju iz članka 13. stavka 1. ZUS-a, jer se ne radi o pravnom pitanju koje bi bilo povezano s nekim mjestom.

\subsubsection{Poštovanje temeljnih načela javne nabave}

Što se tiče (ne)poštovanja temeljnih načela javne nabave iz članka 3. ZJN-a, zauzeta su ova pravna shvaćanja: a) prilikom provođenja postupaka javne nabave, naručitelji su obvezni u odnosu na sve gospodarske subjekte poštovati, između ostalog, načelo razmjernosti, b) svrha odredbi Zakona o javnoj nabavi i na tom zakonu utemeljenih podzakonskih propisa sastoji se, u prvom redu, u zaštiti ravnopravnosti natjecatelja u postupku javne nabave te zaštiti javnog interesa, koji se, među ostalim, očituje u transparentnosti postupka vezanog za angažiranje javnih financijskih sredstava, prevenciji zlouporabe od strane naručitelja, te općenito u zaštiti objektivne zakonitosti, c) u postupcima javne nabave, prilikom interpretacije načela razmjernosti, valja uzeti u obzir je li riječ o imperativnim odredbama ili o odredbama koje razumijevaju manji stupanj vezanosti primjenjivača pravne norme, d) pri tumačenju načela razmjernosti i načela jednakog tretmana, u obzir je potrebno uzeti međusobni odnos tih dvaju načela, kao i njihov odnos s drugim načelima javne nabave i općeg upravnog postupka, kao i njihov odnos s drugim relevantnim normama kojima je uređen postupak javne nabave, e) u okolnostima kada je odabrani ponuditelj, protivno dokumentaciji za nadmetanje, svojoj ponudi priložio certifikat bez prijevoda ovlaštenog prevoditelja na hrvatski jezik, naručitelj, pozivom na načelo razmjernosti, nije bio ovlašten prihvatiti takvu ponudu kao valjanu, a Državna komisija je postupila zakonito kada je poništila odluku o odabiru zbog navedenog propusta, te f) dopuštanje samo jednom ponuditelju da, suprotno dokumentaciji za nadmetanje, izbjegne trošak prijevoda tražene dokumentacije na hrvatski jezik, pri čemu su ostali ponuditelji imali takav trošak, bilo bi protivno načelu jednakog tretmana, a prihvaćanjem takve ponude bila bi narušena ravnopravnost ponuditelja, kao i javni interes te osobito pravna sigurnost u postupku javne nabave. ${ }^{104}$

Po pitanju obveze poštovanja temeljnih načela javne nabave, dva važna pravna shvaćanja izrazio je i Upravni sud u Osijeku. Tako je, u presudi broj UsI-602/12-

102 Rješenja Visokog upravnog suda broj UrII-72/15-2 od 26. ožujka 2015. i UrII-159/15-2 od 29. travnja 2015.

103 Rješenje Visokog upravnog suda, poslovni broj UrII-310/16-2 od 8. lipnja 2016.

104 Ova pravna shvaćanja zauzeo je Upravni sud u Rijeci u presudi broj UsI-344/12-20 od 16. svibnja 2012. - pravomoćna u prvom stupnju. 
18 od 15. siječnja 2013. ${ }^{105}$ izrazio stav da kada su u postupku javne nabave, dokumentacijom za nadmetanje, određeni različiti uvjeti dokazivanja tehničke i stručne sposobnosti za pojedine gospodarske subjekte, opisano postupanje javnog naručitelja nije u skladu s načelima jednakog tretmana i zabrane diskriminacije iz članka 6. stavka 1. ZJN/07. U drugoj presudi, ${ }^{106}$ isti sud je zauzeo ovo: „kada je u stadiju pregleda i ocjene ponuda zatraženo pojašnjenje od samo jednog ponuditelja a ne svih u vezi s dokumentima kojima se dokazuje stručna i tehnička sposobnost, opisano postupanje javnog naručitelja nije u skladu s načelima jednakog tretmana i zabrane diskriminacije iz članka 6. stavka 1 . ZJN/07“.

\subsubsection{Obveznici primjene $Z J N-a$}

Vezano za obveznike primjene ZJN-a, izdvojiti je dva pravna shvaćanja, jedno Upravnog suda u Splitu iz presude broj UsI-1055/12 od 2. studenoga 2012., a drugo Upravnog suda u Osijeku iz presude broj UsI-322/15-10 od 26. studenoga 2015. godine. ${ }^{107}$ Prvo, sud je zauzeo shvaćanje da u okolnostima kada se naručitelj ne nalazi na Popisu obveznika primjene ZJN/07, koji je određen Uredbom o popisu obveznika primjene Zakona o javnoj nabavi, kada ne spada u krug javnih naručitelja koji su obveznici primjene ZJN/07 iz članka 3. stavka 1. ZJN/07, te kada se radi o pravnoj osobi koja za predmet poslovanja ima industrijski i trgovački značaj, zakonito je postupila Državna komisija kada je odbacila žalbu stranke zbog nenadležnosti, zato što nisu ispunjeni kumulativno određeni zakonski uvjeti koji naručitelja čine obveznikom primjene ZJN/07. Potom, sud u Osijeku je smatrao da trgovačka društva koja obavljaju komunalnu djelatnost - dimnjačarske poslove na temelju dobivene koncesije nisu naručitelji iz članka 3. ZJN/07 odnosno članka 5. ZJN-a, te nisu obveznici primjene navedenih zakona. S tim u vezi, kazao je da naručitelj može nabaviti usluge koje se obavljaju na temelju dobivene koncesije u pregovaračkom postupku bez prethodne objave, u kojem slučaju treba podijeliti predmet javne nabave i provoditi otvoreni postupak javne nabave samo za nabavu usluge koja se slobodno nudi na tržištu, jer bi u suprotnom narušio načelo slobode pružanja usluga i načelo tržišnog natjecanja pogodujući ili koncesionaru na štetu ostalih gospodarskih subjekata ako bi ograničio sudjelovanje u nadmetanju samo subjektima koji posjeduju posebno ili isključivo pravo, ili obratno, ako bi uslugu koja je obuhvaćena koncesijom u konačnici dodijelio subjektu koji je nema.

\subsubsection{Razlozi isključenja}

„Raspravljajući“ o razlozima isključenja gospodarskih subjekata u postupcima javne nabave, razlučiti je pravna shvaćanja upravnih sudova koja su se ticala obligatornih razloga isključenja iz članka 67 . ZJN-a od onih koja su iznesena vezano za ostale razloge isključenja iz članka 68 . ZJN-a.

105 Postala je pravomoćna u prvom stupnju.

106 Presuda broj UsI-602/12-18 od 15. siječnja 2013. - pravomoćna u prvom stupnju.

107 Obje odluke postale su pravomoćne u prvom stupnju. 
Vezano za obligatorne razloge isključenja, upravni su sudovi zaključili sljedeće: a) u okolnostima kada su u dokumentaciji za nadmetanje navedena sva kaznena djela iz članka 67. stavka 1. točke 1 . ZJN-a koja su razlog za obligatorno isključenje, te kada je ponuda sadržavala izjavu o nekažnjavanju u kojoj nisu navedena sva kaznena djela iz članka 67. stavka 1. točke 1 . ZJN-a, zakonito je postupio javni naručitelj kada je isključio ponuditelja takve ponude iz postupka javne nabave, ${ }^{108}$ b) kada izjava o nekažnjavanju, protivno dokumentaciji za nadmetanje, ne sadrži sva kaznena djela iz članka 67. stavka 1. točke 1. ZJN-a, nisu ispunjeni uvjeti iz članka 92. ZJN-a za traženje pojašnjenja ili upotpunjavanja takve izjave, jer bi to predstavljalo naknadnu zamjenu već dostavljene dokumentacije, ${ }^{109}$ c) kada izjava o nekažnjavanju na kojoj je samo ovjeren potpis osobe ovlaštene za zastupanje gospodarskog subjekta kod javnog bilježnika, protivno dokumentaciji za nadmetanje i članku 67. stavku 3. Zakona o javnoj nabavi (Narodne novine, broj: 90/11), nije dana ispred javnog bilježnika, zakonito je iz postupka javne nabave isključen ponuditelj ponude koja je sadržavala takvu izjavu ${ }^{110}{ }^{111}$ te d) izjava o nekažnjavanju koja se odnosi samo na osobu ovlaštenu za zastupanje gospodarskog subjekta, a koja nije dana i za gospodarski subjekt, ne predstavlja valjan dokaz o nekažnjavanju, u smislu članka 67. stavka 1 . točke 1 . i stavka 3. točke 3 . ZJN-a. ${ }^{112}$

S druge strane, po mišljenju upravnih sudova, glede ostalih razloga isključenja: a) za postojanje teškog profesionalnog propusta na strani gospodarskog subjekta, kakav ima u vidu odredba članka 68. stavka 7. ZJN-a, dostatna je objektivna procjena naručitelja u svakom pojedinom slučaju, što može biti predmet osporavanja u eventualnom žalbenom postupku, s time da je na žalitelju teret dokaza da s njegove strane nije došlo do profesionalnog propusta, ${ }^{113} \mathbf{b}$ ) težak profesionalni propust, među ostalim, predstavlja propust koji je vezan uz izvršenje ugovora koji je doveo do raskida ugovora ili drugih težih posljedica; s tim u vezi, u okolnostima kada naručitelj nije tražio raskid ugovora ili naknadu štete, te kada na drugi način nije dokazao postojanje istog, na strani gospodarskog subjekta ne bi postojao učinjen težak profesionalni propust, u smislu članka 68. stavka 7 . ZJN-a, ${ }^{114}$ c) težak profesionalni propust zbog kojeg se ponuditelj može isključiti iz postupka javne nabave ne mora biti učinjen na način da je uslijed njega došlo do raskida ugovora, već je dostatno da je konkretni profesionalni propust doveo do težih posljedica, u smislu odredbe članka

108 Presuda Upravnog suda u Rijeci broj UsI-1025/13-11 od 7. studenoga 2014. - pravomoćna u prvom stupnju.

109 Ibidem.

110 Presuda Upravnog suda u Zagrebu broj UsI-3162/13-17 od 10. srpnja 2014. pravomoćna u prvom stupnju.

111 Čl. 9. Zakona o izmjenama i dopunama Zakona o javnoj nabavi (NN, br. 83/13) izmijenjen čl. 67. st. 3. toč. 3. ZJN-a, na način da je regulirana mogućnost da izjava o nekažnjavanju može biti dana i u obliku javnobilježničkog akta, na javnobilježnički zapisnik ili da je na njoj samo ovjeren potpis kod javnog bilježnika.

112 Presuda Visokog upravnog suda poslovni broj Usž-672/15-2 od 17. rujna 2015.

113 Presuda Visokog upravnog suda poslovni broj Usž-1374/15-2 od 9. rujna 2015.

114 Presuda Upravnog suda u Splitu broj UsI-1017/13-7 od 30. rujna 2013. - pravomoćna u prvom stupnju. 
68. stavka 1. točke 4. Zakona o javnoj nabavi („Narodne novine“, broj: 90/11), ${ }^{115}$ d) predstečajna nagodba čije je sklapanje odobreno rješenjem trgovačkog suda prema odredbi članka 66. stavka 9. Zakona o financijskom poslovanju i predstečajnoj nagodbi („Narodne novine“, broj: 108/12, 144/12 i 81/13) ne predstavlja razlog za isključenje natjecatelja ili ponuditelja iz postupka javne nabave, u smislu članka 68. stavka 1. točke 1. i 2. Zakona o javnoj nabavi („Narodne novine“, broj: 90/11 i 83/13) ${ }^{116}$ te e) ako želi koristiti jedan ili više razloga za neobligatorno isključenje gospodarskih subjekata iz postupka javne nabave, naručitelj mora prethodno, u dokumentaciji za nadmetanje, navesti da će ih koristi kao razlog isključenja. ${ }^{117} 118$

\subsubsection{O uvjetima sposobnosti gospodarskih subjekata}

U pogledu uvjeta sposobnosti gospodarskih subjekata, u upravnosudskoj praksi najviše se dvojbi javilo po pitanju pravne i poslovne sposobnosti iz članka 70. ZJN-a i financijske sposobnosti iz članka 71 . ZJN-a, ali i u određenom dijelu glede tehničke i stručne sposobnosti, vezano za primjenu odredbi članka 72. ZJN-a.

\subsubsection{Pravna i poslovna sposobnost}

Prvo, što se tiče pravne i poslovne sposobnosti, izdvojiti je nekoliko zanimljivih pravnih shvaćanja: a) u postupku javne nabave loživa ulja za osnovne škole mogu sudjelovati samo oni gospodarski subjekti koji ispunjavaju uvjete za obavljanje djelatnosti trgovine na veliko naftnim derivatima, zbog čega je naručitelj zakonito postupio kada je, dokumentacijom za nadmetanje, zatražio od ponuditelja da, kao dokaz pravne i poslovne sposobnosti, dostave suglasnost za obavljanje djelatnosti trgovine na veliko loživim uljem ekstra lakim koju izdaje ministarstvo nadležno za poslove gospodarstva, ${ }^{119}{ }^{120}$ b) u slučaju dokazivanja postojanja pravne i poslovne sposobnosti, ako gospodarski subjekt mora posjedovati određeno ovlaštenje ili biti član određene organizacije kako bi mogao izvršiti određeni ugovor ili dio ugovora, natjecatelj ili ponuditelj mora dokazati posjedovanje važećeg ovlaštenja ili članstva za

115 Presuda Upravnog suda u Osijeku broj UsI-547/12-11 od 30. studenoga 2012. - pravomoćna u prvom stupnju. stupnju.

116 Presuda Upravnog suda u Osijeku broj UsI-262/14-6 od 22. travnja 2014. - pravomoćna u prvom

117 Presuda Upravnog suda u Osijeku broj UsI-602/12-18 od 15. siječnja 2013. - pravomoćna u prvom stupnju.

118 Usporedbom čl. 46. st. 2. toč. 4. ZJN/07 sa sadržajem odredbe čl. 68. st. 1. toč. 4. ZJN-a, primijetiti je da je i važećom regulacijom, kao ostali razlog isključenja natjecatelja ili ponuditelja, predviđen težak profesionalni propust, s time da se mora raditi o propustu gospodarskog subjekta koji je učinjen u posljednje dvije godine od početka postupka javne nabave. Dakle, stari ZJN bio je znatno rigidniji za natjecatelje ili ponuditelje, jer nije predviđao vremensko ograničenje vezano za nastanak teškog profesionalnog propusta. Pritom, i ZJN/07, u čl. 46. st. 2., a ZJN, u čl. 68. st. 2., sadrže obvezu naručitelju da, ukoliko želi koristiti jedan ili više razloga za neobligatorno isključenje, mora prethodno navesti da će ih koristi kao razloge isključenja.

119 Presuda Upravnog suda u Rijeci broj UsI-523/12-16 od 13. prosinca 2013. - pravomoćna u prvom stupnju.

120 Čl. 49. st. 1. točka 2. ZJN/07 usporedi s čl. 70. st. 1. i 4. ZJN-a. 
sebe i/ili za podizvoditelja. Dakle, ako je zatražio da svaki član zajednice ponuditelja mora posjedovati ovlaštenje za obavljanje određene djelatnosti, naručitelj je time postrožio zakonske uvjete, pritom onemogućavajući ponuditelja da za određeni dio ugovora o javnoj nabavi angažira podizvoditelja, a dokumentacija za nadmetanje u samo navedenome nije usklađena s odredbom članka 70. stavka 4 . $\mathrm{ZJN}-\mathrm{a},{ }^{121}$ c) pravna i fizička osoba koja obavlja djelatnost servisiranja te isključivanja iz uporabe proizvoda odnosno uređaja za hlađenje i klimatizaciju, mora imati dozvolu nadležnog ministarstva iz članka 27. stavka 1. Uredbe o tvarima koje oštećuju ozonski sloj (NN, br. 120/05), zbog čega je naručitelj bio dužan, dokumentacijom za nadmetanje, kao dokaz pravne i poslovne sposobnosti, odrediti i navedenu dozvolu ministarstva, ${ }^{122}$ te d) u okolnostima kada ugovorena vrijednost javne nabave ne prelazi iznos od 150.000,00 eura, te kada vrijednost pojedinih radova ne prelazi $30.000,00$ eura, član zajednice ponuditelja nije bio u obvezi, kao dokaz pravne i poslovne sposobnosti, dostaviti suglasnost (licencu) za izvođenje određenih radova na svim građevinama, skupina $\mathrm{H}$ iz točke 9.4.5., jer dokumentacijom za nadmetanje takav dokaz nije tražen, a niti je takva suglasnost bila potrebna prema odredbi članka 38. stavka 1., u vezi s člankom 31. Zakona o arhitektonskim i inženjerskim poslovima i djelatnostima u prostornom uređenju i gradnji (NN, br. 152/08, 124/09 i 49/11); ${ }^{123}$ s tim u vezi, isti je sud naveo da za ocjenu je li za određene radove bila potrebna suglasnost nije relevantna vrijednost predmeta javne nabave u smislu ZJN-a, već ugovorena vrijednost radova, kako je to regulirano člankom 31. Zakona o arhitektonskim i inženjerskim poslovima i djelatnostima u prostornom uređenju i gradnji. ${ }^{124}$

\subsubsection{Financijska sposobnost}

Drugo, vezano za financijsku sposobnost, Upravni sud u Rijeci, u presudi poslovni broj UsI-1732/13-16 od 30. siječnja 2015., ${ }^{125}$ zauzeo je nekoliko važnih pravnih shvaćanja. Prvo, zaključio je da je odredba članka 71. stavka 1 . ZJN-a, kojom su regulirani dokazi financijske sposobnosti gospodarskog subjekta u postupku javne nabave, dispozitivne, a ne kogentne prirode. Nadalje, istaknuo je da se financijska sposobnost gospodarskog subjekta po samoj svojoj prirodi ocjenjuje s obzirom na čas podnošenja ponude ili javne objave poziva na nadmetanje, odnosno u vrijeme

121 Presuda Upravnog suda u Rijeci broj UsI-879/14-12 od 22. veljače 2016., koja u vrijeme ovog izlaganja nije postala pravomoćna jer se spis nalazi na Visokom upravnom sudu po žalbi. Međutim, iako se radi o nepravomoćnoj odluci, smatram važnim skrenuti pozornost na nju, zato što, po ocjeni autora, predstavlja svojevrstan važan posredan izvor prava. stupnju.

122 Presuda Upravnog suda u Osijeku broj UsI-1039/12-8 od 8. veljače 2013. - pravomoćna u prvom

123 Zakon o arhitektonskim i inženjerskim poslovima i djelatnostima u prostornom uređenju i gradnji (NN, br. 152/08, 124/09 i 49/11, u daljnjem tekstu: Zakon o arhitektonskim i inženjerskim poslovima i djelatnostima u prostornom uređenju i gradnji).

124 Presuda Upravnog suda u Osijeku broj UsI-1373/14-15 od 12. svibnja 2015. Ova presuda, po žalbi stranke, potvrđena je presudom Visokog upravnog suda broj Usž-1212/15-3 od 12. svibnja 2016.

125 Postala pravomoćna u prvom stupnju. 
koje neposredno prethodi tom vremenskom razdoblju, s obzirom na to da okolnost da je neki subjekt bio financijski sposoban, solventan i likvidan u prethodnom vremenskom razdoblju nema kakvo značenje po njegovu financijsku sposobnost u vrijeme postupka javne nabave. Zaključio je da je zakonodavac, odredbom članka 71. stavka 1. ZJN-a, dokaze financijske sposobnosti odredio samo primjerice, a ne i taksativno (numerus clausus), čime je dopustio da javni naručitelj u pozivu na nadmetanje ili u pozivu na dostavu ponuda, kao dokaz financijske sposobnosti, odredi neki od zakonom predviđenih dokumenata ili druge dokumente koji se mogu dostaviti, uz mogućnost određivanja i starosti dokumenta. I završno, naveo je da norma članka 71. stavka 1. ZJN-a ovlašćuje javne naručitelje da po svojoj slobodnoj volji odluče hoće li odrediti uvjete financijske sposobnosti ili ne, te koje će dokaze (uključujući i njihovu starost) smatrati prikladnima za dokazivanje navedenoga uvjeta sposobnosti. ${ }^{126} 127$

Pritom, Upravni sud u Osijeku, isto tako, zauzeo je, u presudama poslovni broj UsI-184/14-20 od 17. travnja 2015. i UsI-1359/14-7 od 13. ožujka 2015. godine, koje su obje postale pravomoćne u prvom stupnju, nekoliko pravnih shvaćanja na koje smatram da treba skrenuti pozornost. U prvoj odluci, sud je smatrao da javni naručitelj, u smislu odredbi članka 71. stavka 1. i 4. ZJN-a, može slobodno, kao dokaz financijske sposobnosti, odrediti neki od zakonom predviđenih dokumenata ili druge dokumente koji se mogu dostaviti, uz mogućnost određivanja i starosti dokumenta, pod uvjetom da propisivanje starosti dokaza financijske sposobnosti u pojedinom slučaju ne dovede do toga da gospodarski subjekti budu u nejednakom položaju, te da javni naručitelj mora u postupku javne nabave svim gospodarskim subjektima pod jednakim uvjetima omogućiti pribavljanje dokaza, pa i dokaza financijske sposobnosti, kojima oni mogu dokazati ispunjenje postavljenih uvjeta sposobnosti. Dotle, u drugoj odluci sud je zaključio da, kako iz dokumentacije za nadmetanje ne proizlazi izričita obveza da oba člana zajednice ponuditelja moraju dostaviti dokaze financijske sposobnosti, tada se financijska sposobnost dokazuje kumulativno za zajednicu ponuditelja koja predstavlja jednog ponuditelja i koja zajednički dokazuje financijsku sposobnost.

\subsubsection{Stručna i tehnička sposobnost}

Po pitanju stručne i tehničke sposobnosti, sudovi su smatrali: a) odredba članka 72. stavka 3. ZJN-a, kojom su regulirani taksativno dokazi tehničke i stručne sposobnosti gospodarskog subjekta u postupku javne nabave, kogentne je prirode, ${ }^{128}$ b) kada, protivno dokumentaciji za nadmetanje, nije uz ponudu dostavio popis

126 Istovjetna pravna shvaćanja zauzeli su Upravni sud u Rijeci u presudi poslovni broj UsI-340/14-9 od 29. prosinca 2014. te Upravni sud u Osijeku u presudi poslovni broj UsI-729/15-10 od 29. rujna 2015., pri čemu su obje odluke postale pravomoćne danom donošenja, jer protiv njih nije bila dopuštena žalba.

127 Ovakva pravna shvaćanja prvostupanjskih upravnih sudova, vezano za dokazivanje financijske sposobnosti, ,potvrdio“ je i Visoki upravni sud u presudi poslovni broj Usž-378/15-2 od 12. studenoga 2015. godine.

128 Presude Visokog upravnog suda broj Usž-378/15-2 od 12. studenoga 2015. 
značajnih ugovora o izvršenim uslugama, već isključivo potvrdu o urednom izvršenju ugovora, ponuditelj u izloženome nije dokazao svoju stručnu i tehničku sposobnost, jer potvrda o urednom izvršenju ugovora ne sublimira i postojanje samog popisa, a posebno imajući u vidu da je postupak javne nabave strogo formalan postupak, ${ }^{129}$ te c) tumačeći odredbe članka 72. ZJN-a, svrha traženja dokaza o tehničkoj i stručnoj sposobnosti sastoji se u tome da druga ugovorna strana, naručitelj, potvrdi da je ponuditelj iz konkretnog postupka javne nabave već izvršio određene radove ili usluge. ${ }^{130}$

\subsubsection{Dokumentacija za nadmetanje}

Što se tiče sadržaja, načina izrade i postupanja s dokumentacijom za nadmetanje, nekoliko je važnih pravnih shvaćanjazauzeto u upravnosudskojpraksi. Tako su sudovi smatrali da: a) odredba članka 78. stavka 5. ZJN-a, prema kojoj se dokumentacija za nadmetanje izrađuje na hrvatskom jeziku i latiničnom pismu, peremptorne je prirode, b) dokumentacija za nadmetanje može, u skladu s odredbom članka 78. stavka 6. ZJN-a, biti izrađena u cijelosti ili u dijelu i na stranom jeziku ili jezicima, ali je u slučaju spora uvijek mjerodavna dokumentacija za nadmetanje izrađena na hrvatskom jeziku, ${ }^{131}$ c) u postupku javne nabave organiziranog prijevoza djece odnosno učenika osnovne škole od mjesta stanovanja do mjesta škole i obrnuto, naručitelj u dokumentaciji za nadmetanje, kao predmet nabave, nije mogao naznačiti prijevoz učenika osnovnih škola putem javnog linijskog prijevoza, već isključivo putem posebnog linijskog prijevoza, u skladu s odredbama članka 4. točke 29. i članka 53. stavka 1. Zakona o prijevozu u cestovnom prometu („Narodne novine“, broj: 82/13 te članka 1. stavka 2. i članka 2. Pravilnika o uvjetima koje moraju ispunjavati autobusi kojima se organizirano prevoze djeca (,Narodne novine“, broj: 100/08 i 20/09), ${ }^{132}$ d) ZJN, u članku 79. i 81., omogućuje naručitelju da predmet nabave određuje u skladu sa svojim potrebama i da shodno tome određuje predmet nabave kroz tehničke specifikacije uz ograničenja iz Dodatka IV. te u vidu „kriterija jednakovrijednosti“", ${ }^{133}$ te e) tehnička specifikacija, iznimno, može upućivati na posebnu marku ili izvor, ili poseban proces, ili zaštitni znak, patente, tipove ili posebno podrijetlo ili proizvodnju ako se predmet nabave ne može dovoljno precizno i razumljivo opisati na temelju odredbi članka 81. stavka 3. i 4. ZJN-a, ali

129 Presuda Visokog upravnog suda broj Usž-156/13-9 od 13. studenoga 2013. i Usž-216/16-2 od 7. travnja 2016.

130 Presuda Upravnog suda u Zagrebu broj UsI-1142/13-23 do 10. srpnja 2014. - pravomoćna u prvom stupnju.

131 Presuda Upravnog suda u Rijeci broj UsI-2099/13-9 od 3. ožujka 2015. - pravomoćna u prvom stupnju.

132 Presuda Upravnog suda u Osijeku broj UsI-1004/15-14 od 23. listopada 2015. - pravomoćna u prvom stupnju.

133 Presuda Visokog upravnog suda poslovni broj Usž-2409/15-2 od 14. travnja 2016. 
u tom slučaju uz uputu uvijek mora stajati dodatak ,,ili jednakovrijedan“, inače, u suprotnome, dokumentacija za nadmetanje u tom dijelu ne bi bila zakonita. ${ }^{134}$

\subsubsection{Ponuda}

Vezano za odredbe ZJN-a o ponudi, sudovi su smatrali da: a) iskazivanje popusta na cijenu u troškovniku ne čini ponudu nevaljanom, odnosno ona time nije protivna dokumentaciji za nadmetanje, zbog čega nisu ispunjeni razlozi za isključenje takve ponude primjenom odredbe članka 84. stavka 1. točke 7 . ZJN-a, ${ }^{135}$ ${ }^{136}$ b) kada su u ponudi odabrane zajednice ponuditelja ispravci glede obrojčavanja stranica jasno vidljivi i kada je upisano točno obrojčavanje, a u uvjetima kada je ponuda odabrane zajednice ponuditelja uvezana u neraskidivu cjelinu čime je onemogućeno naknadno vađenje ili umetanja listova, unatoč tome da uz ispravak nije naveden datum i da stranica na kojoj je naveden sadržaj ponude nije obrojčana, potonje opisane okolnosti, cijeneći odredbu članka 116. stavka 2. ZUP-a, nisu od utjecaja na valjanost ponude, ${ }^{137}$ c) pri izradi ponude ponuditelj se mora pridržavati zahtjeva i uvjeta iz dokumentacije za nadmetanje, pa je zakonito postupila Državna komisija kada je, na temelju odredbe članka 164. stavka 1. točke 4. ZJN-a, poništila odluku o odabiru ponuditelja koji ponudu nije sastavio u skladu s uvjetima stručne i tehničke sposobnosti iz dokumentacije za nadmetanje, ${ }^{138}$ d) ponuda se zajedno s pripadajućom dokumentacijom izrađuje na hrvatskom jeziku, pa, ukoliko je, suprotno dokumentaciji za nadmetanje, ponuditelj dostavio pripadajuću dokumentaciju u dijelu na stranom jeziku, zakonito je naručitelj isključio takvu ponudu u postupku javne nabave, ${ }^{139}{ }^{140}$ e) smisao zakonskih i podzakonskih normi, kojima je regulirana izrada ponude kao cjeline u postupcima javne nabave, sastoji se u sprečavanju naknadnog nedozvoljenog manipuliranja ponudom, u smislu vađenja ili umetanja dijelova ponude, a ne obezvređivanje čitave ponude uslijed činjenice da je određeni dokument (suprotno dokumentaciji za nadmetanje) dostavljen na stranom jeziku, pod uvjetom da ponuda i bez tog dokumenta, u dijelu u kojem je sastavljena na

134 Presuda Upravnog suda u Rijeci broj UsI-2099/13-9 od 3. ožujka 2015. - pravomoćna u prvom stupnju.

135 Presuda Upravnog suda u Splitu broj UsI-113/12 od 2. studenoga 2012. - pravomoćna u prvom stupnju.

136 Za razliku od ZJN-a, koji je, u čl. 93. st. 1. toč. 4., okolnost da je suprotna odredbama dokumentacije za nadmetanje, regulirao kao razlog odbijanja ponude, ZJN/07 je, u čl. 84. st. 1. toč. 7., navedenu okolnost predvidio kao razlog za isključenje ponude. Dakle, ZJN regulira institut odbijanja ponude, dok ZJN/07 „govori“ o institutu isključenja ponude. Međutim, neovisno o različitim nazivima pravnih instituta, pravne su posljedice za ponuditelja koji je podnio takvu ponudu iste, a sastoje se u isključenju tog ponuditelja od daljnjeg sudjelovanja u konkretnom postupku javne nabave.

137 Presuda Upravnog suda u Osijeku broj UsI-671/14-40 od 25. rujna 2014. - pravomoćna u prvom stupnju.

138 Presuda Visokog upravnog suda poslovni broj Usž-510/15-2 od 11. veljače 2016.

139 Presuda Upravnog suda u Splitu broj UsI-186/12 od 9. listopada 2012. - pravomoćna u prvom stupnju.

140 Gotovo identična odredba sadržana u čl. 87. st. 2. ZJN-a. Međutim, ZJN je, u čl. 93. st. 1. toč. 4., kao posljedicu opisanog postupanja ponuditelja, predvidio odbijanje, a ne isključenje ponude. 
hrvatskom jeziku, ispunjava sve uvjete iz dokumentacije za nadmetanje, ${ }^{141} \mathbf{f}$ ) ZJN, u članku 91. stavku 1. i 2., daje ovlast naručitelju da odbije ponudu ako je u njoj iskazana neuobičajeno niska cijena ponude ili neuobičajeno niska pojedina jedinična cijena što dovodi u sumnju mogućnost isporuke robe, izvođenja radova ili pružanja usluga koje su predmet nabave, pri čemu primjena navedene ovlasti ovisi isključivo o slobodnoj ocjeni naručitelja, što znači da se njome može, ali ne mora koristiti, ${ }^{142} \mathbf{g}$ ) ako se naručitelj odluči koristiti ovlašću iz članka 91. stavka 1. ZJN-a, dužan je prethodno, prije odbijanja ponude, zatražiti pisano objašnjenje s podacima o sastavnim elementima ponude koje smatra bitnima za izvršenje ugovora, u skladu s odredbom članka 92. stavka $2 . \mathrm{ZJN}-\mathrm{a},{ }^{143} \mathbf{h}$ ) u slučaju da ponuda, suprotno dokumentaciji za nadmetanje, sadržava samo dokument na stranom jeziku, naručitelj može, u skladu s odredbama članka 92 . ZJN-a, pozvati ponuditelja da upotpuni ponudu dostavljanjem prijevoda tog dokumenta na hrvatski jezik, što bi se smatralo uklanjanjem nedostatka koji nije utjecao na formu ili sadržaj već predanih dokumenata i što ne bi dovelo do izmjene ponude, ${ }^{144}$ i) ZJN, u članka 92. stavku 1., omogućuje naručitelju da po svojoj slobodnoj ocjeni odluči hoće li tražiti od ponuditelja da pojašnjenjem ili upotpunjavanjem u vezi s dokumentima traženima sukladno člancima 67. do 74. tog Zakona uklone pogreške, nedostatke ili nejasnoće koje se mogu ukloniti, dakle, navedenom zakonskom normom nije predviđena obveza opisanog postupanja naručitelja, ${ }^{145}$ te j) pojašnjenje ili upotpunjavanje iz članka 92. stavka 1. i 2.ZJN-a smije se odnositi samo na nejasnoće, manje nedostatke ili pogreške koji su otklonjivi, što ne smije imati za rezultat naknadu zamjenu ili dostavu traženih dokumenata. ${ }^{146}$

\subsubsection{Redovna pravna zaštita}

Analizirajući pravnu zaštitu gospodarskih subjekata, izdvojiti je nekoliko aktualnih i zanimljivih pravnih shvaćanja. Tako su sudovi, po pitanju ovlasti i sadržaja odluke Državne komisije, zaključili: a) žalitelj je prekludiran osporavati zakonitost dokumentacije za nadmetanje nakon proteka zakonskih rokova za izjavljivanje takve žalbe, u stadiju postupka u kojem je izjavljena žalba protiv odluke o odabiru, a Državna komisija pazi po službenoj dužnosti samo na bitne povrede koje su počinjene u stadiju postupka u kojoj je izjavljena žalba sukladno člancima 146. do 153 . ZJN-a, b) kako u postupku javne nabave nije osporena njezina zakonitost unutar rokova koje predviđa ZJN, okolnost da je dokumentacija

141 Presuda Upravnog suda u Rijeci broj UsI-535/13-17 od 10. rujna 2014. - pravomoćna u prvom stupnju.

142 Presuda Upravnog suda u Rijeci broj UsI-1342/13-12 od 27. veljače 2015. - pravomoćna u prvom stupnju.

143 Ibidem.

144 Presuda Upravnog suda u Rijeci broj UsI-535/13-17 od 10. rujna 2014. - pravomoćna u prvom stupnju.

145 Presuda Upravnog suda u Rijeci broj UsI-1025/13-11 od 7. studenoga 2014. - pravomoćna u prvom stupnju.

146 Ibidem. 
za nadmetanje očito zahvaćena nezakonitošću nije od utjecaja na zakonitost pobijane odluke o odabiru, ${ }^{147} 148$ te c) zakonita je odluka Državne komisije, u kojoj je, u izreci, navedeno da se poništava dokumentacija za nadmetanje ,u dijelu kojem je zahvaćena nezakonitošću“ a bez potankog naznačavanja u kojem je dijelu dokumentacija za nadmetanje nezakonita, pod uvjetom da je u obrazloženju odluke potanko objašnjeno u kojem je precizno dijelu poništena dokumentacija odnosno u kojem je dijelu zahvaćena nezakonitošću. ${ }^{149}$

Iznoseći o pravu na žalbu, sudovi su zaključili: a) okolnost da je gospodarski subjekt u postupku javne nabave imao status ponuditelja ne znači nužno da on ima i pravo na žalbu, u smislu članka 141. stavka 1. ZJN-a, b) da bi postojalo pravo na izjavljivanje žalbe prema odredbi članka 141. stavka 1. ZJN-a, moraju biti kumulativno ispunjena oba uvjeta: da postoji ili da je postojao pravni interes fizičke, pravne i/ili zajednice fizičkih i/ili pravnih osoba za dobivanje određenog ugovora o javnoj nabavi ili okvirnog sporazuma, te da su te osobe pretrpjele ili bi mogle pretrpjeti štetu od navodnoga kršenja subjektivnih prava, ${ }^{150}$ c) kumulativni uvjeti za podnošenje žalbe iz članka 141. stavak 1. ZJN-a obuhvaćaju pravni interes za dobivanje određenog ugovora o javnoj nabavi i moguću štetu za gospodarskog subjekta, d) ponuditelj koji ne može sklopiti ugovor o javnoj nabavi, jer mu je u postupku javne nabave ponuda ocijenjena nevaljanom, nije oštećen niti mu prijeti opasnost da bude oštećen eventualnom nezakonitošću donesene odluke o odabiru, radi čega je zakonito postupila Državna komisija, kada je, primjenom članka 164. stavka 1. točke 2. ZJN-a, odbacila žalbu tog ponuditelja zbog nedostatka pravnog interesa, e) ponuditelj koji ne može sklopiti ugovor o javnoj nabavi, jer mu je u postupku javne nabave ponuda izvršnim a nepravomoćnim rješenjem ocijenjena nevaljanom, nije oštećen niti mu prijeti opasnost da bude oštećen eventualnom nezakonitošću donesene odluke o odabiru, zbog čega je zakonito postupila Državna komisija, kada je, primjenom članka 164. stavka 1. točke 2. ZJN-a, odbacila žalbu tog ponuditelja zbog nedostatka pravnog interesa, bez obzira na okolnost što je $u$ tijeku upravni spor koji se vodi radi ocjene zakonitosti odluke kojom je ponuda ocijenjena nevaljanom, a imajući u vidu da tužba u upravnom sporu, u pravilu, nema odgodni učinak prema članku 26. stavku 1. ZUS-a, f) postojanje prava na žalbu odnosno ispunjenje kumulativnih uvjeta za izjavljivanje žalbe iz članka 141. stavak 1. ZJN-a na strani određenog gospodarskog subjekta ispituje Državna komisija u svakom pojedinom žalbenom postupku, ${ }^{151}$ te g) ponuditelj koji ne može sklopiti ugovor o javnoj nabavi, jer mu je u postupku javne nabave ponuda, pravomoćnim

147 Ova dva shvaćanja zauzeo je Upravni sud u Osijeku u pravomoćnoj presudi broj UsI-970/13-15 od 28. II. 2014.

148 Slično tome zaključio je i Upravni sud u Splitu u pravomoćnim presudama poslovni broj UsI2045/12-15 od 4. rujna 2013. i UsI-2044/12-18 od 7. veljače 2014.

149 Presuda Upravnog suda u Rijeci broj UsI-1628/13-16 od 15. X. 2014. - pravomoćna u prvom stupnju.

150 Presuda Visokog upravnog suda poslovni broj Usž-1121/15-2 od 4. veljače 2016.

151 Iznesena pravna shvaćanja izražena u presudi Visokog upravnog suda broj Usž-990/15-2 od 23. ožujka 2016. 
rješenjem javnopravnog tijela, ocijenjena nevaljanom, nije oštećen niti mu prijeti opasnost da bude oštećen eventualnom nezakonitošću donesene odluke o odabiru, zbog čega je zakonito postupila Državna komisija, kada je, primjenom članka 164. stavka 1. točke 2 . ZJN-a, odbacila žalbu tog ponuditelja zbog nedostatka pravnog interesa. ${ }^{152}$

U ovom dijelu skrenuti je pozornost i na nekoliko odluka Upravnog suda u Rijeci koji je ,,raspravljajući“ o pitanju postojanja prava na žalbu zauzeo neka važna pravna shvaćanja. Sud je po ovom pitanju smatrao da: a) u žalbenom postupku žalitelj je dužan dokazati da sudjelovanjem u konkretnom postupku javne nabave može konkurirati za dobivanje ugovora o javnoj nabavi, te da je pretrpio ili da bi mogao pretrpjeti štetu od navodnoga kršenja subjektivnih prava, b) gospodarski subjekt, čija je ponuda pravomoćno odbijena jer je suprotna dokumentaciji za nadmetanje, ne može sklopiti ugovor o javnoj nabavi i ne može biti oštećen niti mu prijeti opasnost da bude oštećen eventualnom nezakonitošću odluke o odabiru drugog ponuditelja, shodno čemu nema pravo na žalbu protiv odluke o odabiru zbog nedostatka pravnog interesa, ${ }^{153}$ c) pravni interes za dobivanje određenog ugovora o javnoj nabavi u smislu članka 141. stavka 1 . ZJN-a ne može se poistovjetiti niti uzročno-posljedično povezati sa sposobnošću za dobivanje ugovora koji je predmet javne nabave, s obzirom na to da se navedene dvije procesne pretpostavke ispituju u različitim stadijima otvorenog postupka javne nabave, d) sposobnost za sudjelovanje u otvorenom postupku javne nabave ispituje naručitelj u stadiju nakon zaprimanja ponuda, dakle nakon što je dokumentacija za nadmetanje ili potvrđena odlukom Državne komisije donesenom povodom žalbe protiv iste ili je pak stekla svojevrsnu konačnost i pravomoćnost time što nije osporena njezina zakonitost, e) ispitivanje pravnog interesa pojedinog žalitelja za podnošenje žalbe protiv dokumentacije za nadmetanje, kao procesne pretpostavke za podnošenje žalbe protiv iste, predstavlja radnju koju obavlja tuženik povodom izjavljene žalbe protiv dokumentacije za nadmetanje, dakle u ranijem stadiju otvorenog postupka javne nabave, dok još ponude nisu ni podnesene, te stoga ponuditelji još nisu niti poznati, f) Državnoj komisiji nije zakonom dopušteno upuštati se u ocjenu sposobnosti gospodarskih subjekata, žalitelja da sudjeluju u otvorenom postupku javne nabave u odnosu na (ne)postojanje pravne i poslovne sposobnosti prema uvjetima sposobnosti koje je (žalbom osporenom) dokumentacijom za nadmetanje odredio naručitelj, a koji nisu izrijekom regulirani odredbama ZJN-a, u stadiju postupka javne nabave u kojem je izjavljena žalba protiv poziva na nadmetanje i dokumentacije za nadmetanje, ${ }^{154}$ g) kako je predmet javne nabave bila nabava komunalnog vozila za skupljanje komunalnog i selektiranog otpada putem financijskog leasinga, odnosno sklapanje

152 Presuda Upravnog suda u Osijeku broj UsI-35/13-6 od 26. VI. 2013. (pravomoćna u prvom stupnju). Slično je, po pitanju prava na žalbu u predmetima javne nabave, tumačeći čl. 141. st. 1. ZJN-a, zaključio i Upravni sud u Splitu u pravomoćnim presudama poslovni broj UsI-2045/12-15 od 4. IX. 2013. i UsI-2044/12-18 od 7. II. 2014.

153 Presuda broj UsI-377/13-9 od 31. X. 2014. - pravomoćna u prvom stupnju. Identično pravno shvaćanje zauzeo je i Upravni sud u Osijeku u presudi broj UsI-257/14-6 od 22. VII. 2014. (pravomoćna danom donošenja).

154 Presuda poslovni broj UsI-1732/13-16 od 30. siječnja 2015. - pravomoćna u prvom stupnju. 
ugovora o financijskom leasingu, a cijeneći okolnost da djelatnost leasinga mogu obavljati samo leasing-društva iz članka 3. ZL-a, te da gospodarski subjekt nije registriran za obavljanje djelatnosti financijskog leasinga i da nema odobrenje za obavljanje poslova leasinga koje izdaje Hrvatska agencija za nadzor financijskih usluga, zakonito je odbačena žalba takvog gospodarskog subjekta izjavljena protiv dokumentacije za nadmetanje zbog nedostatka pravnog interesa, te h) postojanje prava na žalbu iz članka 141. stavka 1 . ZJN-a na strani određenog žalitelja ispituje Državna komisija u svakom pojedinom slučaju neovisno o tome u kojem je stadiju postupka žalba izjavljena. ${ }^{155} 156$

Glede sadržaja žalbe i postupanja s neurednom i nepravovremenom žalbom, valja ukazati na nekoliko pravnih shvaćanja koja su se pokazala vrlo važnima po pitanju razmatranja cijelog sustava javne nabave, ali i uloge Državne komisije u postupcima javne nabave. Tako su sudovi zaključili: a) svrha obveze žalitelja da dostavi primjerak žalbe i naručitelju iz članka 145. stavka 3. ZJN-a sastoji se u omogućavanju ostvarivanja suspenzivnog učinka žalbe, a koja svrha je ostvarena samom činjenicom da je žalitelj primjerak žalbe podnio i naručitelju (i Državnoj komisiji) prije isteka zakonskih žalbenih rokova, što ne mora nužno biti $\mathrm{u}$ istom trenutku kada je žalbu izjavio Državnoj komisiji, zbog čega je, pretjerano formalističkim i restriktivnim tumačenjem odredbe članka 145. stavka 3. ZJN-a, nezakonito odbačena žalba kao nepravodobna, ${ }^{157}{ }^{158}$ b) u okolnostima kada žalba nije pristigla Državnoj komisiji u zakonskom žalbenom roku zbog nemogućnosti zaprimanja i obrađivanja pošiljki od strane davatelja poštanskih usluga uslijed poteškoća $s$ informatičkim sustavom prisutnih $u$ vrijeme podnošenja žalbe na čitavom području Republike Hrvatske, a kada je žalba pravovremeno izjavljena poštom i preporučenom pošiljkom unutar zakonskog roka iz članka 146. stavka 1. točke 4. ZJN-a, nisu bili ispunjeni uvjeti za odbačaj žalbe kao nepravodobne primjenom članka 164. stavka 1 . točke $2 . \mathrm{ZJN}-\mathrm{a},{ }^{159}$ c) zahtjev za objašnjenjem vezano za dokumentaciju za nadmetanje iz članka 31. stavka 3. ZJN-a gospodarski subjekt može podnijeti i nakon što je protekao rok za izjavljivanje žalbe u odnosu na dokumentaciju za nadmetanje u otvorenom postupku javne nabave iz članka 146. stavka 1. točke 1 . ZJN-a, slijedom čega i žalbu koja se odnosi na propuštanje

155 Presuda broj UsI-2019/14-7 od 29. svibnja 2015. - pravomoćna u prvom stupnju, s obzirom na to da žalba, iako je bila dopuštena, nije izjavljena.

156 Istovjetno pravno shvaćanje vezano za postojanje prava na žalbu u slučaju kada je predmet javne nabave bila nabava vozila za skupljanje i selektiranje otpada putem financijskog leasinga izrazio je i Upravni sud u Osijeku u presudi broj UsI-1124/14-13 od 20. siječnja 2015. koja je postala pravomoćna u prvom stupnju, s obzirom na to da žalba, iako je bila dopuštena, nije izjavljena. Ova pravna shvaćanja su oprečna pravnom shvaćanju izraženom u presudi Upravnog suda u Rijeci poslovni broj UsI-1732/13-16 od 30. siječnja 2015. stupnju.

157 Presuda Upravnog suda u Osijeku broj UsI-951/14-7 od 20. X. 2015. - pravomoćna u prvom

$158 \mathrm{U}$ tumačenju odredbe čl. 145. st. 3. ZJN-a oprečno pravno shvaćanje izrazio je Upravni sud u Splitu u presudi poslovni broj UsIjn-23/14-12 od 29. lipnja 2015., koja je postala pravomoćna, s obzirom na to da tužitelj nije iskoristio žalbu iako je u konkretnom slučaju bila dopuštena.

159 Presuda Upravnog suda u Osijeku broj UsI-1553/15-10 od 22. ožujka 2016. - pravomoćna u prvom stupnju. 
naručitelja da stavi na raspolaganje objašnjenja određenih nejasnoća dokumentacije za nadmetanje nije nužno izjaviti u roku za izjavljivanje žalbe u odnosu na sadržaj dokumentacije za nadmetanje, d) pri ocjeni pravodobnosti žalbe koja je izjavljena zbog propuštanja naručitelja da stavi na raspolaganje objašnjenja određenih nejasnoća dokumentacije za nadmetanje valja primijeniti odredbu članka 153. $\mathrm{ZJN}-\mathrm{a}$, zbog čega je ponuditelj takvu žalbu trebao izjaviti u roku od 10 dana od dana primitka odluke kojom se odlučuje o njegovom pojedinačnom pravu, odnosno u konkretnom slučaju od dana primitka odluke o odabiru najpovoljnije ponude, ${ }^{160}$ e) kada je žalba upućena poštom preporučeno ili predana ovlaštenom pružatelju poštanskih usluga, dan predaje pošti, odnosno ovlaštenom pružatelju poštanskih usluga smatra se danom predaje javnopravnom tijelu kojem je upućena, što znači da je zakonodavac uvjete predaje podneska poštom preporučeno ili predaje ovlaštenom pružatelju poštanskih usluga postavio alternativno, odnosno, opisane radnje predaje podneska u upravnom postupku izjednačene su po svom učinku, u smislu članka 72. stavka 2. ZUP-a, ${ }^{161}{ }^{162}$ f) kako nije predana preporučenom pošiljkom ili pošiljkom predanoj ovlaštenom pružatelju poštanskih usluga pod kojim se ne može smatrati i pružatelj koji obavlja ostale poštanske usluge iz članka 16. stavka 3. Zakona o poštanskim uslugama („Narodne novine“, broj: 144/12 i 153/13), tada se dan predaje žalbe ima smatrati danom kada je zaprimljena u javnopravnom tijelu kojem je upućena, zbog čega je zakonito postupila Državna komisija kada je odbacila žalbu kao nepravodobnu, jer je u času njezina zaprimanja u tijelu kojem je upućena protekao zakonski žalbeni rok. ${ }^{163} 164$

U ovom dijelu posebno želimo skrenuti pozornost na pravomoćnu odluku Upravnog suda u Splitu poslovni broj UsI-2219/12-9 od 11. rujna 2014. godine, kada je taj sud, vezano za postupanje s (ne)urednom žalbom i obvezom prilaganja dokaza o uplati naknade za pokretanje žalbenog postupka, zauzeo ovo pravno shvaćanje: „Kada je nesporno uplatio naknadu za pokretanje žalbenog postupka, te kada je ta transakcija nesporno izvršena u korist Državnog proračuna u traženom iznosu i zbog tražene svrhe, a cijeneći okolnost da iz zaključka Državne komisije ne proizlazi

160 Presuda Upravnog suda u Zagrebu broj UsI-4160/12-8 od 15. travnja 2013. - pravomoćna u prvom stupnju.

161 Presuda Upravnog suda u Osijeku broj UsI-534/15-11 od 12. studenoga 2015. - pravomoćna u prvom stupnju.

162 Tumačeći čl. 72. ZUP-a u predmetu javne nabave, Ustavni je sud, u odluci broj U-III-4459/2012 od 21. IV. 2016., istaknuo: ,... Iz obrazloženja zaključka Državne komisije i presude Visokog upravnog suda proizlazi da su oni ispitali podnesak podnositelja kao da je on upućen preporučenom poštom. Suprotno tome, podnositelj je predao podnesak ovlaštenom pružatelju poštanskih usluga, koja je radnja u ZUP-u izjednačena s upućivanjem podnesaka preporučenom poštom. Stječe se dojam da su Državna komisija i Visoki upravni sud članak 72. stavak 2. ZUP-a selektivno tumačili te potpuno zanemarili veznik ,ili“" i drugi dio odredbe koja dozvoljava da se podnesak preda ovlaštenom pružatelju poštanskih usluga. Pri tome za svoj pristup nisu dali nikakvo obrazloženje pa su ostali nejasni razlozi zbog kojih smatraju da takva predaja ovlaštenom pružatelju poštanskih usluga nema isti učinak odnosno da nije izjednačena s upućivanjem pošiljke preporučenom poštom...".

${ }_{163}$ Presuda Upravnog suda u Osijeku broj UsI-1042/14-13 od 26. studenoga 2014. - pravomoćna u prvom stupnju.

164 Istovjetno pravno shvaćanje u pogledu tumačenja i primjene čl. 72. st. 2. ZUP-a izraženo je i u pravomoćnoj presudi Upravnog suda u Osijeku broj UsI-807/14-12 od 7. listopada 2014. 
da je žalitelj pozvan da dostavi dokaz o plaćanju predmetne naknade u izvorniku, te da takva obveza žalitelja (da dostavi dokaz o uplati naknade u izvorniku) ne proizlazi niti iz odredbe članka 159. stavka 1. točke 9. Zakona o javnoj nabavi („Narodne novine“, broj, 90/11), u konkretnom slučaju nisu ispunjeni zakonski uvjeti za odbačaj žalbe kao neuredne““. ${ }^{165} 166167168169170171$

K tome, po pitanju sadržaja žalbe, navesti je još tri zanimljiva pravna shvaćanja. Naime, sudovi su zauzeli stav: a) dokaz o uplati naknade za pokretanje žalbenog postupka podrazumijeva da je naknada zaista i uplaćena odnosno platna transakcija izvršena, zbog čega (neprovedeni) nalog za plaćanje ne predstavlja valjan dokaz o uplati takve naknade, u smislu odredbe članka 143. stavka 2. ZJN/07, ${ }^{172}{ }^{173}$ b) žalitelj je dužan uz žalbu ili naknadno, po pozivu Državne komisije, dostaviti dokaz o uplati naknade za pokretanje žalbenog postupka, pa okolnost da je žalitelj zaista uplatio naknadu za pokretanje žalbenog postupka u traženom iznosu i zbog tražene svrhe, a u uvjetima kada nije dostavio takav dokaz uz žalbu ili po pozivu, nije od utjecaja na ocjenu (ne)urednosti žalbe u postupku javne nabave, ${ }^{174}$ te c) u postupku javne nabave stranka je dužna u žalbi navesti žalbeni zahtjev, u skladu s člankom 159. stavkom 1. točkom 8. ZJN-a, koja kao specijalna u odnosu na ZUP kojim se općenito uređuje opći upravni postupak, regulira obvezatan sadržaj žalbe u tim vrstama postupaka. ${ }^{175}$

165 Čl. 169. st. 1. toč. 9. izvornog teksta ZJN-a (bez izmjene NN, br. 83/13) suštinski je istovjetna ranijoj odredbi čl. 143. st. 2. ZJN/07, prema kojoj je također žalitelj bio u obvezi uz žalbu priložiti i dokaz o uplati naknade za vođenje postupka.

166 Slično ovome zaključio je i Upravni sud u Osijeku u pravomoćnoj presudi broj UsI-661/15-8 od 11. rujna 2015 .

167 Ovom presudom suda u Splitu poništen je osporeni zaključak, s time da je tuženoj dana jasna uputa da odluči o osnovanosti (meritumu) izjavljene žalbe. Međutim, Državna komisija u ponovnom postupku, odlučujući o žalbi, nije postupila po pravnom shvaćanju i primjedbama upravnog suda u skladu s čl. 81. st. 2. ZUS-a.

168 Izraženo pravno shvaćanje vezano za tumačenje i primjenu članka 159. stavak 1. točke 9. i članka 169. stavak 4. i 5. ZJN-a istovjetno je shvaćanju VUSRH-a izraženome u kasnijoj presudi broj Usž1213/15-2 od 1. X. 2015.

169 Oprečno pravno shvaćanje u istom predmetu javne nabave izrazio je Upravni sud u Splitu u kasnijoj presudi poslovni broj UsI-2342/12-9 od 25. svibnja 2015., koja je, povodom žalbe tužitelja, preinačena presudom Visokog upravnog suda poslovni broj Usž-1213/15-2 od 1. listopada 2015.

170 Oprečno pravno shvaćanje zauzeo je Upravni sud u Rijeci u presudama broj UsI-208/12-23 od 19. XII. 2012. i UsI-1356/13-12 od 9. VI. 2014., koje su postale pravomoćne u prvom stupnju jer žalba nije bila dopuštena.

171 Glede tumačenja i primjene članka 159. stavka 1. točke 9. i članka 169. stavka 4. i 5. ZJN-a, ali i temeljne svrhe žalbenih postupaka u javnoj nabavi, vidjeti odluku Ustavnog suda broj III-4885/2012 od 3. VII. 2014. stupnju.

172 Presuda Upravnog suda u Rijeci broj UsI-208/12-23 od 19. XII. 2012. - pravomoćna u prvom

173 Ovakvo pravno shvaćanje zauzeto je i u presudama suda u Rijeci broj UsI-115/12-17 od 16. X. 2012. i UsI-529/13-11 od 12. IX. 2014., koje su postale pravomoćne u prvom stupnju, s obzirom na to da Žalba nije bila dopuštena.

174 Presuda Upravnog suda u Rijeci broj UsI-115/12-17 od 16. listopada 2012. - pravomoćna u prvom stupnju.

175 Presuda Visokog upravnog suda poslovni broj Usž-2493/15-2 od 27. siječnja 2016. 


\subsubsection{Naknada troškova žalbenog postupka}

I krajnje, vezano za naknadu troškova žalbenog postupka, također izdvojiti je nekoliko aktualnih pravnih shvaćanja.

Tako su upravni sudovi po ovom pitanju zaključili: a) u slučaju kada je žalba u cijelosti usvojena i poništena natječajna dokumentacija u traženom dijelu u kojem je zahvaćena nezakonitošću, žalitelj ima pravo na naknadu cjelokupnog troška žalbenog postupka, u smislu odredbi članka 170. stavka 3. i 5. ZJN-a, pri čemu nije relevantno jesu li pritom svi žalbeni navodi (prigovori) ocijenjeni osnovanima, ${ }^{176}$ te b) u slučaju kada je u postupku javne nabave žalitelj djelomično uspio svojim žalbenim zahtjevom, s obzirom na to da mu je usvojen zahtjev za poništenjem dokumentacije za nadmetanje u dijelu kojim je obuhvaćena nezakonitošću te da mu je odbijen zahtjev za poništenjem poziva za nadmetanje, zakonito je, primjenom odredbe članka 170. stavka 5. ZJN-a, Državna komisija odlučila da svaka stranka snosi svoje troškove. ${ }^{177}$

\section{ZAKLJUČAK}

Pozitivnopravno uređenje sustava javne nabave opterećuje u određenim segmentima površnost i nedorečenost propisa, što je otežalo rad primjenjivačima propisa u javnopravnim tijelima i upravnoj grani sudovanja. K tome, postoje neki važni segmenti u regulativi i praksi koji zahtijevaju dodatnu analizu i praćenje. Uklanjanjem ovih nedostataka ZJN bi mogao postati primjer kvalitetne regulacije sustava javne nabave, čime bi se ojačao cjelokupni domaći gospodarski sistem, a, s druge strane, spriječila arbitrarnost, podložnost nelegitimnim utjecajima, neodgovornost i samovolja u postupanju i odlučivanju u postupcima javne nabave.

Aktualnu upravnosudsku praksu kao izvora prava, kada govorimo o predmetima javne nabave, a posebno cijeneći dvostupanjski upravni postupak, ustanovljeno novo ustrojstvo upravnih sudova, proširen sadržaj upravnosudskog nadzora i zaštite, prosječne rokove rješavanja upravnih sporova i gotovo trogodišnje razdoblje suženog „filtra“ žalbe, ${ }^{178}$ kao i sadržaj Izvješća o radu Državne komisije za 2012., 2013. i 2014. godinu, posebno u dijelu broja primljenih, riješenih i ostalo neriješenih žalbenih predmeta, obilježilo je nekoliko temeljnih značajki: a) fragmentarnost, s

176 Presuda Visokog upravnog suda poslovni broj Usž-734/15-2 od 17. prosinca 2015. 2016.

177 Presude Visokog upravnog suda broj Usž-1828/15-2 od 26. XI. 2015. i Usž-2493/15-2 od 27. I.

178 Tek novelom ZUS-a s kraja prosinca 2014. (NN, br. 152/14) značajno je proširena redovna pravna zaštita od odluka prvostupanjskih upravnih sudova. O novim pravnim lijekovima u upravnom sporu vidjeti Vezmar Barlek, I., „Pravni lijekovi u upravnosudskom postupku“, Zbornik radova Pravnog fakulteta u Splitu, Split, 2010., str. 113-129. O postupanju i ovlastima te dilemama koje su se pojavile u praksi Visokog upravnog suda u žalbenim predmetima vidjeti i Galić, A., Đerđa, D., „Zalba u upravnom sporu“, Zbornik radova Pravnog fakulteta u Splitu, Split, 2014., str. 339-362; Vezmar Barlek, I., „Ovlasti žalbenog suda u upravnom sporu“, Zbornik Pravnog fakulteta Sveučilišta u Rijeci, Rijeka, 2013., str. 589-606; te Rostaš-Beroš, L., „Dileme u primjeni novog zakona o upravnim sporovima“", Zbornik radova Pravnog fakulteta u Splitu, Split, 2013., str. 473-481. 
obzirom na to da je mali broj odluka uopće osporavan pred upravnim sudovima, b) nepotpunost, jer značajan broj odluka prvostupanjskih upravnih sudova nije podvrgnut ocjeni zakonitosti u žalbenom postupku, c) (u pravilu) ujednačenost, osim što se raznoliko postupanje javilo iznimno i vezano za primjenu pojedinih instituta javne nabave, te d) neaktualnost, posebno imajući u vidu učestalost normativnih promjena. Naime, raznolikost se pojavila po pitanju: a) ocjene (ne)postojanja prava na žalbu, b) ocjene (ne)urednosti žalbe vezano za obvezu dokazivanja odnosno dostavu dokaza o uplati naknade za pokretanje žalbenog postupka te obvezu dostave navedenog dokaza u izvorniku ili preslici, te c) ocjene pravodobnosti žalbe kroz aspekt primjene članka 145. stavka 3. ZJN-a.

Analizom pravomoćnih odluka, u praksi sporni aspekti sustava javne nabave ticali su se prvenstveno dvojbi po pitanju: a) mjesne nadležnosti upravnih sudova u predmetima javne nabave, b) (ne)poštovanja temeljnih načela javne nabave, c) tko bi bili obveznici primjene ZJN-a, d) razloga isključenja gospodarskih subjekata iz postupaka javne nabave, e) uvjeta sposobnosti gospodarskih subjekata, f) sadržaja, načina izrade i postupanja s dokumentacijom za nadmetanje, g) sadržaja, načina izrade i postupanja s pristiglim ponudama, $h$ ) redovne pravne zaštite te i) naknade troškova žalbenog postupka.

K tome, u upravnosudskoj praksi zabilježen je značajan broj slučajeva u kojima se Državna komisija u ponovnom postupku, u izvršenju pravomoćnih presuda, a nakon što je osporena odluka poništena i predmet vraćen na ponovni postupak, suprotno odredbi članka 81. važećeg ZUS-a, nije pridržavala pravnih shvaćanja i primjedaba upravnog suda. Ovakvo postupanje nitko sebi ne bi smio dopustiti, a pogotovo ne javnopravna tijela. Uz to, u praksi Državne komisije zabilježeni su slučajevi pretjeranog pravnog formalizma u tumačenju pravnih normi, poglavito vezano za ocjenu pravovremenosti i urednosti žalbe. Ovakav način postupanja Državne komisije podriva same temelje svakog uređenog pravnog poretka, te $\mathrm{u}$ bitnom narušava načela vladavine prava i pravne sigurnosti.

Međutim, očekivati je u narednom razdoblju da će značajniju ulogu u ujednačavanju upravnopravne prakse i primjene prava u postupcima pred javnopravnim tijelima i upravnim sudovima prvog stupnja, pa i po pitanju javnih nabava, imati Visoki upravni sud, što i jest njegova fundamentalna zadaća. To će ujedno doprinijeti učinkovitijoj zaštiti pravne sigurnosti svih dionika koji sudjeluju u ovim vrstama postupaka. 


\section{Literatura:}

\section{Knjige i radovi:}

1. Aviani, D.; Đerđa, D, „Uniformno tumačenje i primjena prava te jedinstvenost sudske prakse u upravnom sudovanju“, Zbornik radova pravnog fakulteta $u$ Splitu, Split, 2012.

2. Čović, S., Juras, D., Vučkov, D., „Neka pitanja u regulaciji radnopravnog statusa državnih službenika“, Zbornik Pravnog fakulteta Sveučilišta u Rijeci, Rijeka, 2015.

3. Galić, A., Đerđa, D., „Žalba u upravnom sporu“, Zbornik radova Pravnog fakulteta u Splitu, Split, 2014.

4. Ljubanović, B., Britvić-Vetma, B., „Hrvatsko pravo javne nabave - usklađenost s pravom EU“, Zbornik radova Pravnog fakulteta u Splitu, Split, 2011.

5. Kolar, T., Loboja, A., Vuić Z., Primjena Zakona o javnoj nabavi $i$ novih podzakonskih propisa, Inženjerski biro, Zagreb, 2012.

6. Kregar, J., Korupcija: neznanje nije opravdanje, Centar za demokraciju i pravo, Zagreb, 2010.

7. Raguž, G., Blažević Z., Otvoreni postupak javne nabave kroz praksu Državne komisije za kotrolu postupaka javne nabave, „Temporis savjetovanje“ d. o. o., Zagreb, 2014.

8. Rostaš-Beroš, L., „Dileme u primjeni novog zakona o upravnim sporovima“, Zbornik radova Pravnog fakulteta u Splitu, Split, 2013.

9. Šarin, D., „Pravo na pristup sudu u praksi Europskog suda za ljudska prava“, Pravni vjesnik, Zagreb, 2015.

10. Šuler, I., Lerman B., Zovko K., Palčić, I., Javna nabava - službeni stavovi $i$ sudska praksa, Tip4PIN d. o. o., Zagreb, 2015.

11. Uzelac, A., Pravo na pravično suđenje u građanskim predmetima: nova praksa Europskog suda za ljudska prava i njen utjecaj na hrvatsko pravo i praksu, Pravni fakultet Sveučilišta u Zagrebu, Zagreb, 2010.

12. Vezmar Barlek, I., „Pravni lijekovi u upravnosudskom postupku“, Zbornik radova Pravnog fakulteta u Splitu, Split, 2010.

13. Vezmar Barlek, I., „Ovlasti žalbenog suda u upravnom sporu“, Zbornik Pravnog fakulteta Sveučilišta u Rijeci, Rijeka, 2013.

\section{Vrela s interneta}

14. www.eur-lex.europa.eu/en/treaties/index.htm

15. www.transparency.hr

16. www.javna-nabava.hr/.../Statisticko-izvjesce-JN-2015. pdf.

17. www.dkom.hr/.../32004L0017hrv2.pdf 
18. www.dkom.hr/default.aspx?id=25

19. www.sredisnjanabava.hr/.../Direktiva2014/18EZpdf.

20. www.sabor.hr/Default.aspx?art $=40365$

21. www.usud.hr

\section{Praksa sudova i upravnih tijela}

22. Visoki upravni sud Republike Hrvatske, sudska pisarnica, statistički podaci autoru su predani dopisom tajništva tog suda, poslovni broj 9 Su-311/2016-2 od 1. srpnja 2016., koji je zaprimljen u Upravnom sudu u Splitu 6. srpnja 2016., s time da su isti dopunjeni putem e-pošte 25. kolovoza 2016.

23. Upravni sud u Splitu, sudska pisarnica, statistički podaci predani su autoru neposredno i putem e-pošte 29. lipnja 2016.

24. Upravni sud u Zagrebu, sudska pisarnica, statistički podaci predani su autoru elektroničkim putem (e-pošte) tijekom srpnja i kolovoza 2016.

25. Upravni sud u Rijeci, sudska pisarnica, statistički podaci predani su autoru elektroničkim putem (e-pošte) tijekom srpnja i kolovoza 2016.

26. Upravni sud u Osijeku, sudska pisarnica, statistički podaci predani su autoru elektroničkim putem (e-pošte) tijekom srpnja i kolovoza 2016.

27. Presude Visokog upravnog suda Republike Hrvatske dostavljene su autoru dopisom tajništva tog suda, poslovni broj 9 Su-311/2016-2 od 1. srpnja 2016., koji je zaprimljen u Upravnom sudu u Splitu 6. srpnja 2016.

28. Presude Upravnog suda u Splitu dostavljene su autoru putem e-pošte tijekom srpnja i kolovoza 2016.

29. Presude Upravnog suda u Zagrebu dostavljene su autoru putem e-pošte tijekom srpnja i kolovoza 2016.

30. Presude Upravnog suda u Rijeci dostavljene su autoru putem e-pošte tijekom srpnja i kolovoza 2016.

31. Presude Upravnog suda u Osijeku dostavljene su autoru putem e-pošte tijekom srpnja i kolovoza 2016. 


\section{CURRENT ADMINISTRATIVE COURT PRACTICE IN THE PROCEDURE OF PUBLIC PROCUREMENT}

Under the current conditions of complex and difficult economic and social circumstances and given the comparative possibilities and economic effects, the system of public procurement which is firstly at a legal level regulated by the Public Procurement Act 8 (Zakon o javnoj nabavi) of 2011 (further referred to as: PPA $(Z N)$, is of particular importance for the entire legal, political and economic system of the Republic of Croatia. Public procurement in essence represents contracting the procurement of goods, works or services. The specifities of that system are comprised, above all, of regulation of entering contractual relations between the public and private sector. Therefore, this system in principle must be formal in order to protect equality of competitors in the public procurement procedure and also in the general interest. Appreciating the legal tradition and indigenous particularities, the author's fundamental aims consisted of providing and analysing administrative court practice in the context of international legal acquis communautaire showing some legal regulation in practice of disputable aspects of the system of public procurement in Croatia and the doubts emerging from current administrative court practice.

Key words: public procurement; public client; legal protection; right to appeal; costs of procedure; State Commission, administrative dispute. 